University of Nebraska - Lincoln

DigitalCommons@University of Nebraska - Lincoln

4-6-2018

\title{
T.D.A. Cockerell (1866-1948) of the University of Colorado: his contributions to the natural history of the California islands and the establishment of Channel Islands National Monument
}

Daniel R. Muhs

Follow this and additional works at: https://digitalcommons.unl.edu/usgsstaffpub

Part of the Geology Commons, Oceanography and Atmospheric Sciences and Meteorology Commons, Other Earth Sciences Commons, and the Other Environmental Sciences Commons

This Article is brought to you for free and open access by the US Geological Survey at DigitalCommons@University of Nebraska - Lincoln. It has been accepted for inclusion in USGS Staff -- Published Research by an authorized administrator of DigitalCommons@University of Nebraska - Lincoln. 


\title{
T.D.A. Cockerell (1866-1948) of the University of Colorado: his contributions to the natural history of the California islands and the establishment of Channel Islands National Monument
}

\author{
Daniel R. Muhs ${ }^{1, *}$ \\ ${ }^{1}$ U.S. Geological Survey, MS 980, Box 25046, Federal Center, Denver, CO 80225
}

\begin{abstract}
Aвstract.-Theodore Dru Alison Cockerell was a naturalist at the University of Colorado from 1904 to 1947 and studied botany, zoology, and paleontology in North and South America, Asia, Australia, Africa, and Europe. In the latter part of his career, he studied the California islands and published many papers on their natural history, 16 of them in four years (1937-1940). He made important contributions to the natural history of the islands in four distinct ways: entomology of the islands, including identification of a number of new species of bees; discovery of fossil marine invertebrate faunas and recognition that the zoogeography of the taxa reflects the position of the islands relative to converging cool and warm currents; discovery of abundant land snails, both living and in fossil form, and recognition that the fossils are in close stratigraphic association with mammoth fossils; and island biogeography, with considerations of species dispersal mechanisms and endemism. Newly discovered letters and memos also reveal that Cockerell played a pivotal role in the establishment of Channel Islands National Monument.
\end{abstract}

Resumen.-Theodore Dru Alison Cockerell fue un naturalista de la Universidad de Colorado entre los años 1904 a 1947. Estudió botánica, zoología y paleontología de Norte y Sur América, Asia, Australia, África y Europa. Al final de su carrera, estudió las islas de California y publicó numerosos artículos sobre su historia natural, 16 de ellos en cuatro años (1937-1940). Realizó importantes contribuciones a la historia natural de las islas, en cuatro distintas formas: (1) describió la entomología de las islas, incluida la identificación de varias especies nuevas de abejas, (2) descubrió fósiles de invertebrados marinos y reconoció que la zoogeografía de los taxones refleja la posición de las islas en relación con las corrientes convergentes frías y cálidas, (3) descubrió abundantes caracoles terrestres, tanto formas vivas como fósiles y reconoció que los fósiles se encuentran en una estrecha asociación estratigráfica con los fósiles de mamut, y (4) describió la biogeografía de las islas, considerando los mecanismos de dispersión de especies y endemismo. Cartas e informes recientemente descubiertas también revelan que Cockerell jugó un papel fundamental en el establecimiento del Monumento Nacional de las Islas del Canal.

The purpose of this paper is to highlight some of the contributions of an exceptional scientist, Theodore Dru Alison Cockerell, to our understanding of the natural history of the California Channel Islands. In addition to providing some of the first studies of the natural history of the islands in the first half of the 20th century, Cockerell is hypothesized to have played a pivotal role in the decision to establish Channel Islands National Monument in the 1930s, which was later to become Channel Islands National Park. Newly discovered archival evidence from the University of Colorado-Boulder and the National Archives-San Bruno provides a test of this hypothesis and reveals a remarkable story of how important scientific input is to the creation of national parks.

The life of Cockerell (Fig. 1a) is an interesting one and Weber $(2000,2004)$ provides an admirable summary. Cockerell was born in Norwood, a suburb of London, U.K., in 1866. As a young man, he attended private schools in England but never earned a university degree of any kind. When he was in his early $20 \mathrm{~s}$, he contracted tuberculosis and moved to West Cliff (now Westcliffe), Colorado, where he lived for three years. It was in West Cliff where he began studying plants and animals of Colorado. Cockerell returned to England in 1890, thinking he was cured of tuberculosis, and worked under Alfred Russel Wallace at

*Corresponding author: dmuhs@usgs.gov 
(a)

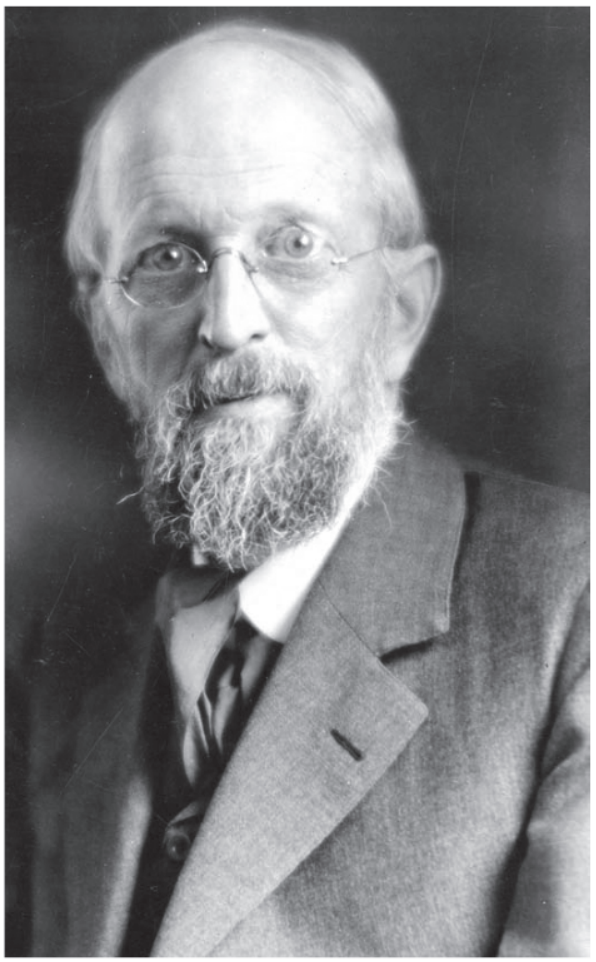

(b)

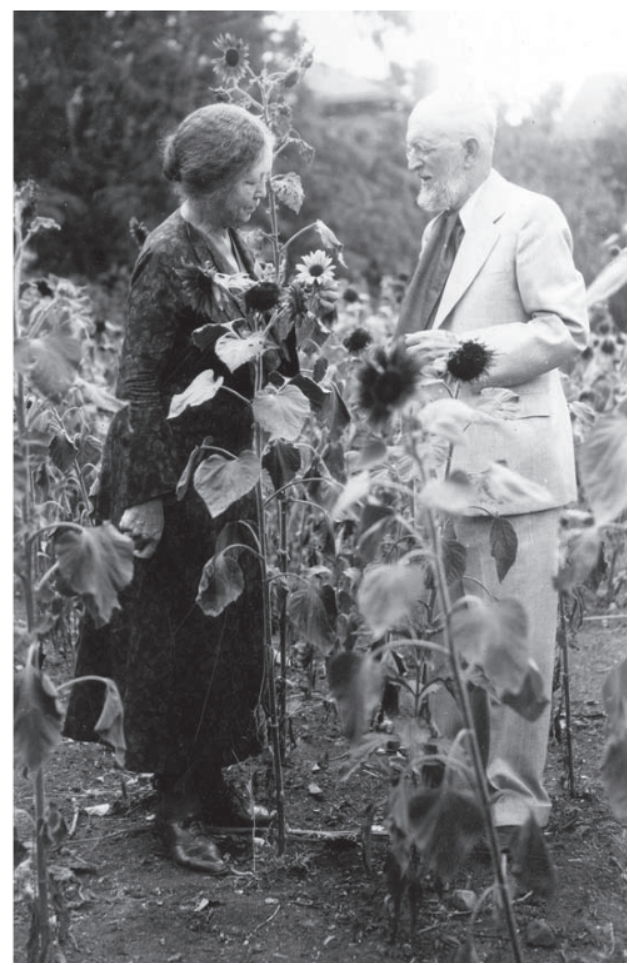

(c)

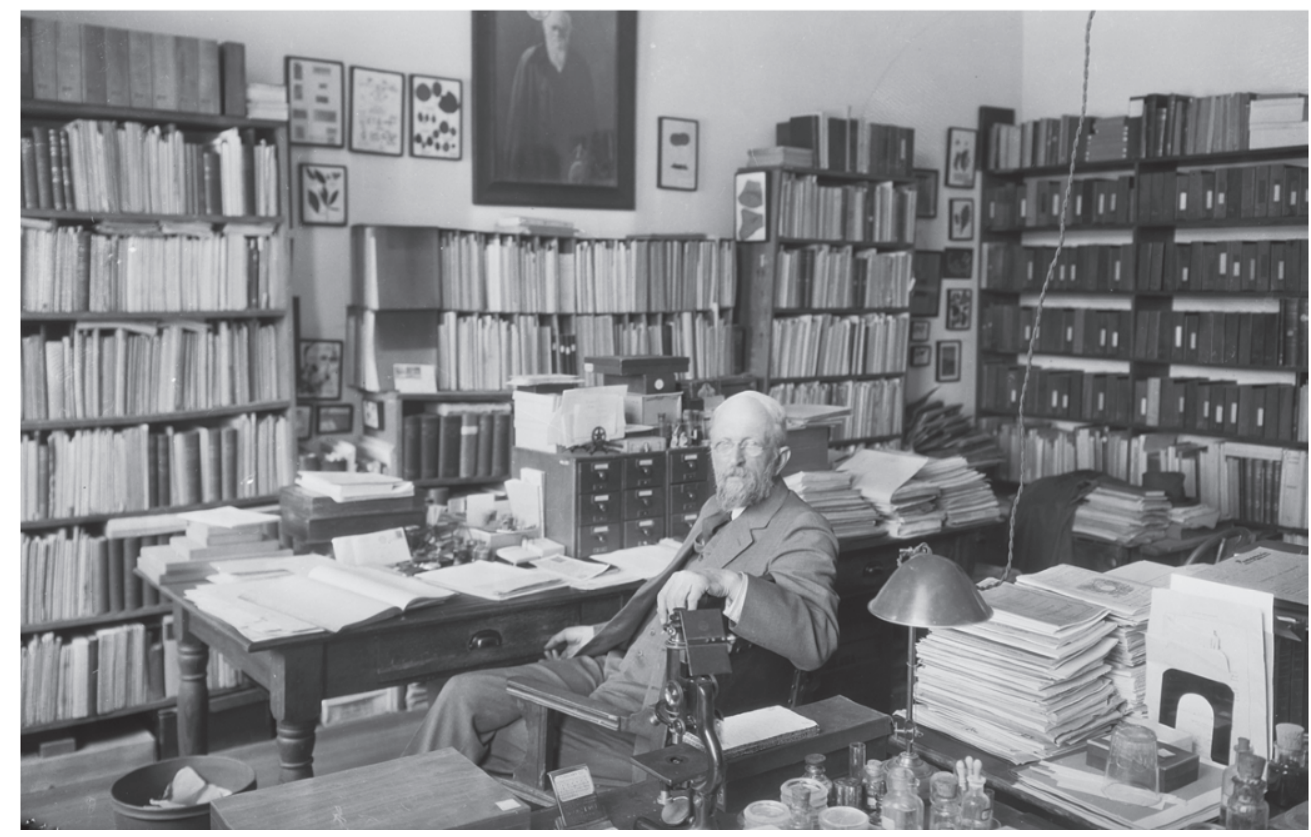

Fig. 1. (a) Theodore D.A. Cockerell portrait (University of Colorado Special Collections, Box 90, Folder 7, Number 7; V.P.C. and T.D.A. Cockerell Morgue Files from the Boulder Daily Camera); (b) T.D.A. and Wilmatte Cockerell in their red sunflower garden in Boulder, Colorado (University of Colorado Special Collections, Box 90, Folder 7, envelope 4; V.P.C. and T.D.A. Cockerell Morgue Files from the Boulder Daily Camera); (c) T.D.A. Cockerell in his study at the University of Colorado, Boulder (University of Colorado Special Collections, Box 92, Folder 1, Number 2). 


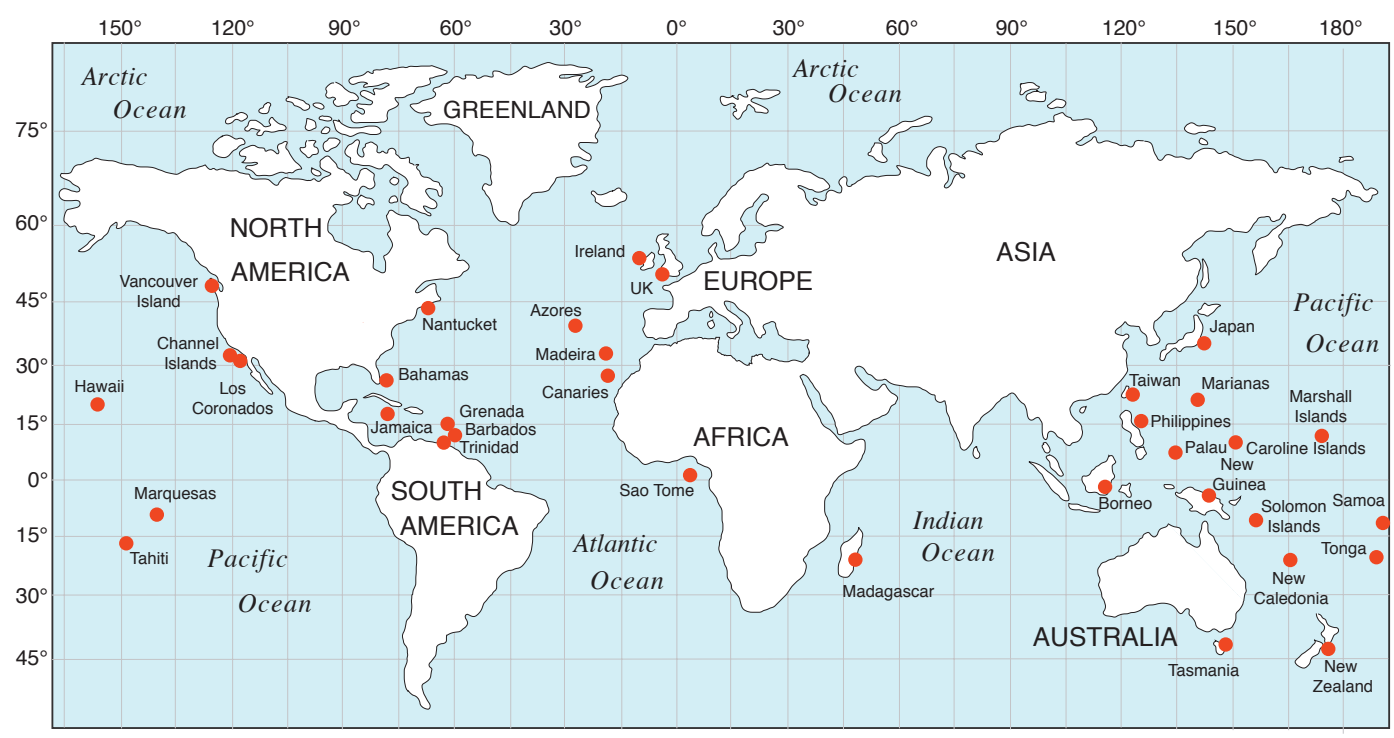

Fig. 2. Map of the world showing islands where T.D.A. Cockerell worked or published studies on collections made by others. Derived from the bibliography of Cockerell's work compiled by Weber (1965).

the British Museum. Wallace was a natural historian who independently recognized natural selection at the same time as Darwin and is often referred to as the father of biogeography. Wallace (1895) specifically acknowledges Cockerell's role as a research and editorial assistant in the preface to the 2nd edition of his classic Island Life. Following this, Cockerell served as a museum curator in Kingston, Jamaica. In 1892, symptoms of tuberculosis appeared again and Cockerell returned to the United States, this time to New Mexico, where he was a university professor. He became a naturalized U.S. citizen in 1898 and married his second wife, Wilmatte Porter (Fig. 1b), in 1900; they had no children. Wilmatte was to become his lifelong partner in research, accompanying him on travels around the world. The couple moved back to Colorado in 1903, first to Colorado Springs, where Cockerell served as museum curator at Colorado College, and ultimately to Boulder in 1904, where he began his career teaching and conducting research at the University of Colorado. He retired formally in 1934, but continued working in the field, as well as his office (Fig. 1c), laboratory, and the University of Colorado Museum. In their retirement years in the 1940s, the Cockerells spent winters in California, where Cockerell was curator of the Desert Museum in Palm
Springs (exact start date is unknown but thought to be 1941-1945 [Weber 2000]).

During his career, Cockerell did fieldwork in North America, Central America, South America, Europe, Africa, Australia, and Asia, and published an astonishing 3904 papers (Weber 1965). Cockerell is notable for the depth of his contributions (particularly in the field of entomology) and the breadth of his work, which spanned entomology, malacology, botany, paleontology, and biogeography. He was also an early advocate of women's rights, wrote essays on philosophy, religion, and ethics, and even wrote poetry and drama. Cockerell was awarded honorary Sc.D. degrees from Colorado College (1913) and the University of Denver (1942). He died on 26 January 1948 in San Diego, California, and is buried in Columbia Cemetery, Boulder, Colorado.

As an assistant to Alfred Russel Wallace in 1890, when the classic Island Life was being revised for its second edition, Cockerell became interested in islands, island biogeography, and insular endemics. Over his long career, he collected plant and animal specimens (or examined specimens collected by others) from islands and island chains all over the world (Fig. 2). Although his earliest published comments on animals of the California Channel Islands go back to the turn of the century (Cockerell 1901), much of his 


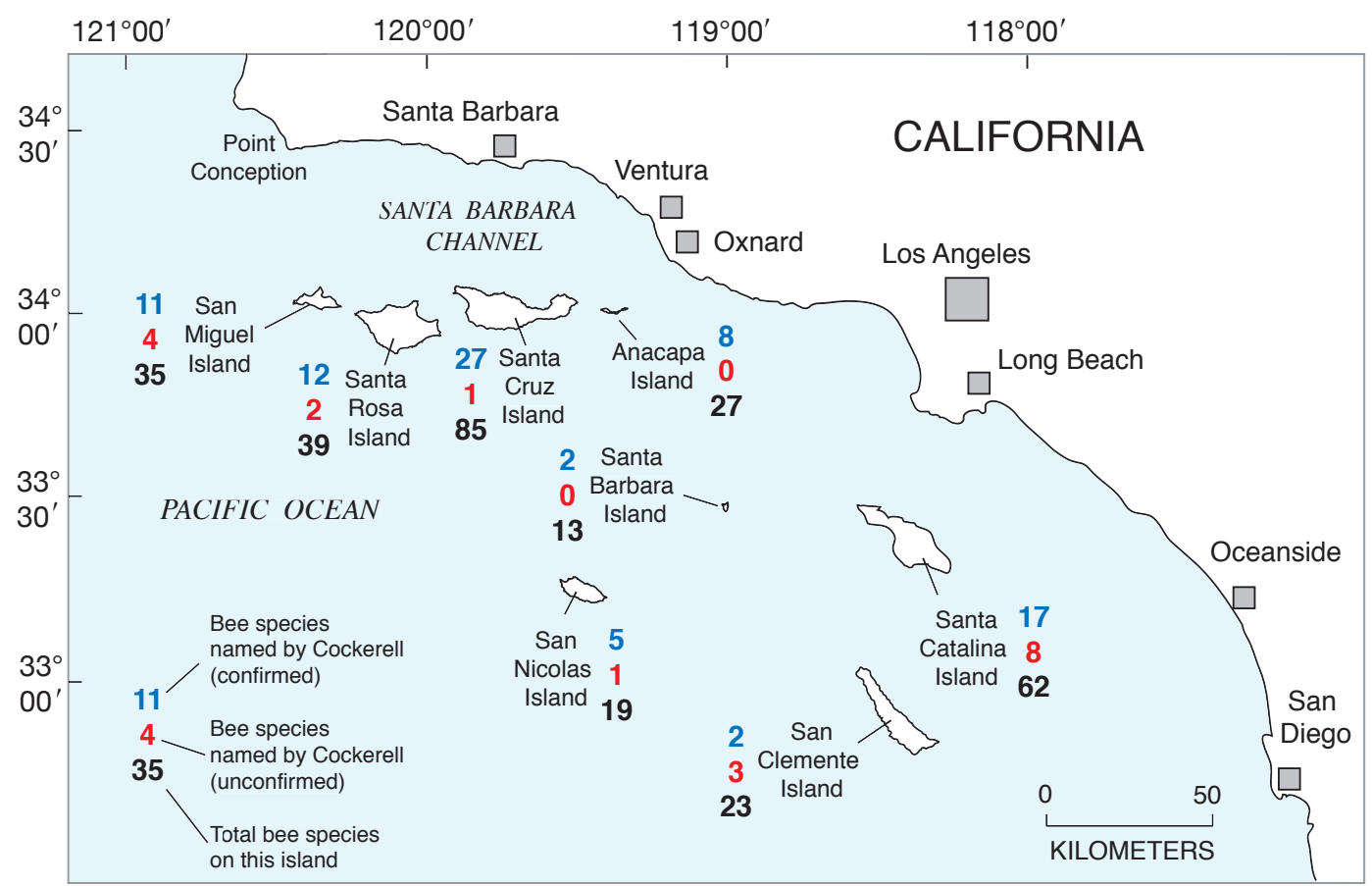

Fig. 3. Map of the Channel Islands, showing the number of confirmed (blue) and unconfirmed (red) extant bee species on the Channel Islands named by T.D.A. Cockerell; also shown are total bee species (black) on each island. Derived from data in Rust et al. (1985).

work on these islands was concentrated in his later years. He visited five of the islands (Santa Catalina, San Clemente, San Nicolas, San Miguel, and Santa Cruz) in the years 1937-1938 and examined specimens that he collected himself or by others from all eight of the islands. He published 16 papers on the California islands during just a four-year period from 1937 to 1940.

\section{Cockerell AND THE ENTOMOLOGY OF THE CHANNEL ISLANDS}

Despite his interests in botany, marine invertebrate zoology, and paleontology, Cockerell was best known for his contributions to entomology, particularly bees. His work and influence in this field are so tremendous that he is still cited as one of the most important figures on the subject in the most recent comprehensive texts (Michener 2007, Wilson and Messinger Carril 2015). Indeed, Michener (2007, p. xii) described him as "the principal bee taxonomist in North America if not the world." Fittingly, many of Cockerell's contributions to the biology of the California islands are also in the field of entomology, primarily with the identification of new species of bees, but also wasps and mealybugs (Cockerell 1937a, 1938a, 1938b, 1939a, 1939b, 1939c, 1940a). Miller (1985) pointed out that Cockerell was one of the few entomologists working on the Channel Islands in the 1930s and was basically a "one man operation," as he put it. Nevertheless, Cockerell was responsible for naming 51 of the bee species found on the Channel Islands, plus 4 wasp species and 4 mealybug species (Rust et al. 1985). Species named by Cockerell are found on all eight of the Channel Islands (Fig. 3). Of the 51 species named by Cockerell, 14 were still considered as of 1985 to be insular endemics, found only on a number of the islands (Miller 1985).

\section{Cockerell and Marine InVertebrate Zoogeography and Terrace Fossils ON THE CHANNEL ISLANDS}

Marine faunal provinces, also referred to in recent years as global biogeographic units, have been developed by a number of investigators over the years. Two of the best-known 


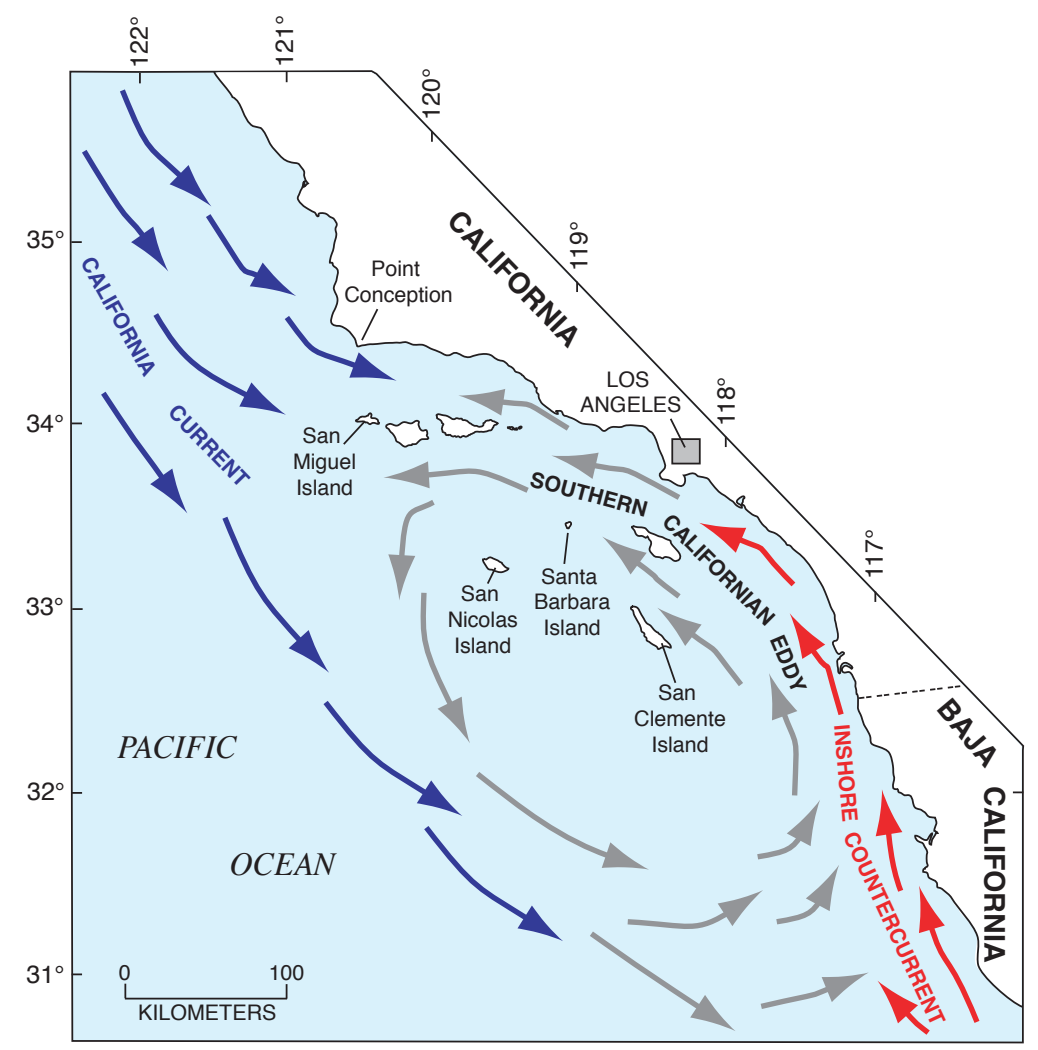

Fig. 4. Map of southern California showing contrasting cold (California Current) and warm (Inshore Countercurrent) currents as described by Cockerell $(1939 \mathrm{~d}, 1940 \mathrm{~b})$ and their proximity to the Channel Islands (map modified from Hendy 2010).

portrayals of global marine faunal provinces are those of Valentine (1973) and Spalding et al. (2007). The Valentine (1973) scheme is based largely on shared species and species diversity. In contrast, the Spalding et al. (2007) scheme is based, for the most part, on patterns of endemism. Belanger et al. (2012) showed that biogeographic units for both these schemes can be predicted with $89 \%-100 \%$ accuracy by a very limited number of variables, the most important of which are temperature, salinity, and productivity. Indeed, temperature alone correctly predicts $53 \%-99 \%$ of the biogeographic structure along coastlines globally.

Along the Pacific Coast of North America, distinct molluscan provinces also have been identified (Valentine 1966). Two of these provinces, the Oregonian and Californian, have a boundary at Point Conception, California, where the coastline shifts from a north-south orientation to an east-west one (Fig. 4). The cold, southward-flowing California Current, running parallel to the coast of California, continues southward well offshore from the mainland California coast south of Point Conception. The warm, northward-flowing Inshore Countercurrent bathes the southern California coast south of Point Conception. Researchers have recognized the distinctive shift in marine faunal compositions at Point Conception as a result of these contrasting currents for well over a century (see review in Hewatt 1946).

Where these two contrasting currents meet, the Southern Californian Eddy forms, and the Channel Islands are situated within this region. As a result, the Channel Islands can be influenced by very cold waters from the north or very warm waters from the south. Cockerell (1939d, 1940b) recognized the unusual position of the Channel Islands with respect to these thermally contrasting currents. He drew parallels between the Channel Islands and the Galapagos Islands, which are in a similar position with respect to contrasting ocean 


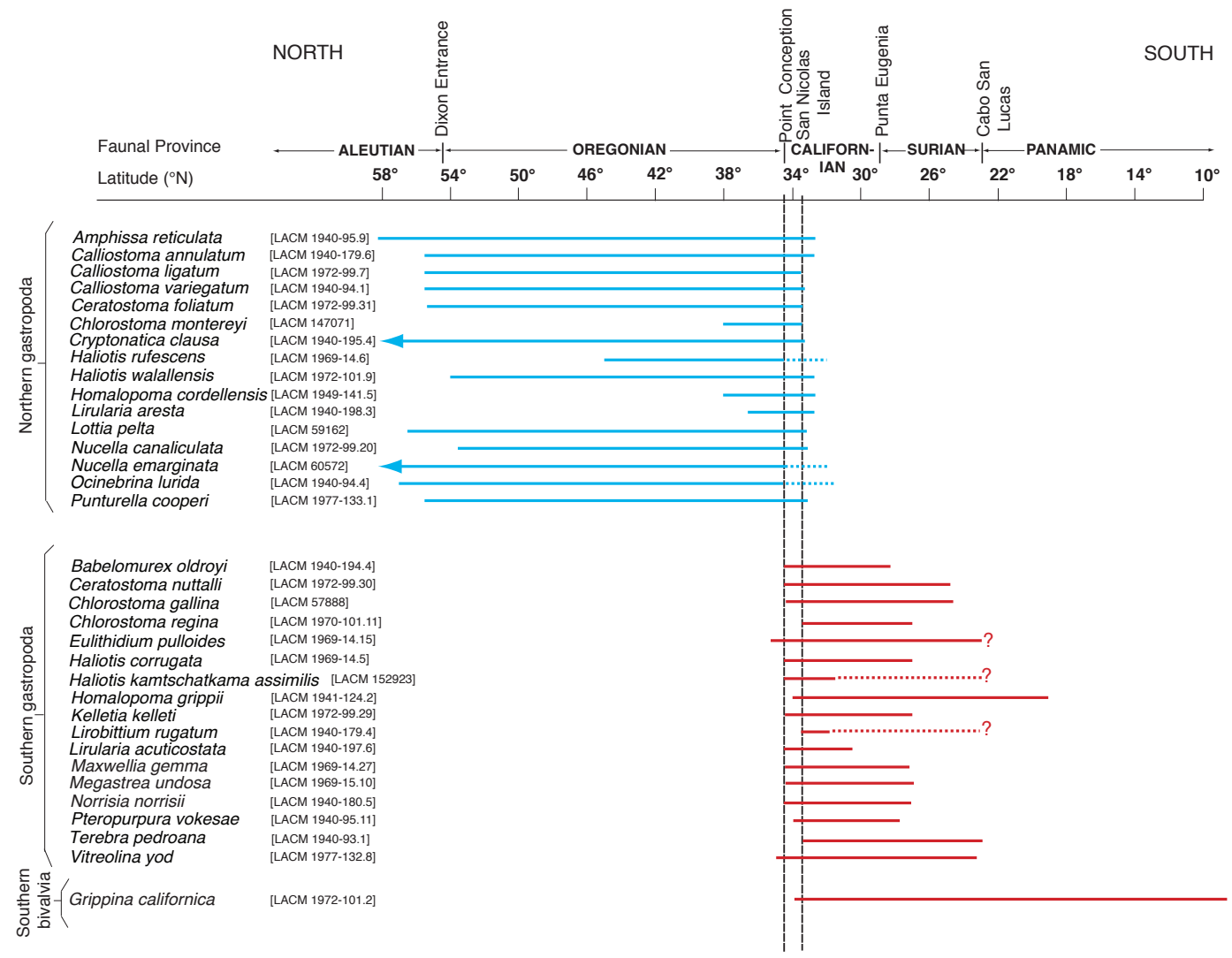

Fig. 5. Graph showing the modern distribution, by latitude, of modern northward- and southward-ranging taxa found in the waters around San Nicolas Island today, confirming the hypothesis of diverse taxa on the islands presented by T.D.A. Cockerell (1939d, 1940b). Data are from records from the Natural History Museum of Los Angeles County (LACM). Geographic distributions are taken from Abbott (1974), McLean (1978), Abbott and Haderlie (1980), Coan et al. (2000), and records from the Natural History Museum of Los Angeles County.

currents, namely the cold, northward-flowing Peru (Humboldt) Current against the warm, southward-flowing Panama Current and warm, eastward-flowing Cromwell Current. Cockerell (1940b) pointed out that because of exposure to both currents, the marine invertebrate communities of the Channel Islands should have a greater diversity than would normally be expected. As a test of Cockerell's hypothesis, one can consider San Nicolas Island, one of the outermost islands, and certainly one that is exposed to both the cold California Current and the warm Inshore Countercurrent (Fig. 4). This island has excellent records of the modern invertebrate marine fauna in the Malacology Section of the Natural History Museum of Los Angeles County (LACM), as well as from individual studies (e.g., Russell 1991, Seapy and Littler 1993). A compilation of modern species documented by LACM collections in the waters around San Nicolas Island shows that there are many taxa whose modern range endpoints occur at or near San Nicolas Island (Fig. 5). Importantly, there are about equal numbers of northward-ranging and southwardranging species, supporting the hypothesis presented by Cockerell (1940b) that a molluscan community with a geographically diverse composition should be expected. Cockerell's hypothesis and its support from this exercise are important because paleoceanographic interpretations based on fossil faunal records have often relied not only on the presence of extralimital species of mollusks, but also on the presence of northward-ranging and southwardranging species (e.g., Muhs et al. 2012, 2014).

Cockerell was also a pioneer in the investigation of the fossil marine molluscan record of 
the California Channel Islands. Although by the 1930s there had been a number of studies of such fossils in the marine terrace deposits of the California mainland, studies of this kind on the Channel Islands were rare and usually in the form of a casual note that fossils were present, but without identifications of species. Indeed, Cockerell was one of the earliest investigators to document the presence of Pleistocene molluscan fossils on higher marine terraces of three of the Channel Islands, San Miguel Island, San Nicolas Island, and San Clemente Island (Cockerell 1938d, 1939e, 1940b). Cockerell was aided in this work by Professor A. Myra Keen of Stanford University, who had just published an extensive work on Pacific Coast Mollusca (Keen 1937). In his 1938 paper, Cockerell documented fossils on San Miguel Island, which he states were found "near the ranch house." The ranch house of that time was at an elevation of $\sim 166 \mathrm{~m}$ above sea level. Here, Cockerell documented the presence of 11 species of mollusks (both bivalves and gastropods), including the extinct Pleistocene species Calicantharus fortis. On San Nicolas Island, Cockerell (1938c, 1940b) reported fossils at an elevation between $\sim 120 \mathrm{~m}$ and $\sim 150 \mathrm{~m}$ and documented the presence of 13 species of mollusks (both bivalves and gastropods), again including the extinct $C$. fortis. On San Clemente Island, Cockerell (1939e, 1940b) reported the occurrence of 33 species of mollusks at an elevation of $\sim 260 \mathrm{~m}$ at a locality "about the middle of the top of the island," where the U.S. Navy had uncovered a fossil bed "in the course of operations." It is not known with certainty where this locality is, but given the description and elevation, it is very likely near where the older airfield is found on the island. Construction of this airfield was completed in 1933, but improvements were made in 1938 and the runways were ready for use by 1939 (Shettle 1997), indicating that the "operations" Cockerell refers to likely were airfield improvements. In support of this interpretation, I have personally confirmed that there are marine terrace deposits here, with a fossil locality at $\sim 260 \mathrm{~m}$ elevation and situated at $32.94375^{\circ} \mathrm{N}$, $118.52904^{\circ} \mathrm{W}$. The locality is also registered with the Natural History Museum of Los Angeles County as LACMIP locality 12577 in their database. Thus, it is likely that this is at least close to where Cockerell (1939e) made his collection. This site is thus far the highest fossil-bearing marine terrace deposit yet discovered on San Clemente Island (Fig. 6). In addition to the species listed by Cockerell (1939e, 1940b), I found specimens of the aforementioned extinct species Calicantharus fortis from this deposit. The presence of the extinct gastropod C. fortis at relatively high elevations on all three islands indicates that these are some of the oldest Pleistocene marine terrace fossils in coastal California. Extrapolating the uplift rates for these islands summarized in Muhs et al. (2014) indicates that Cockerell's fossil locality on San Nicolas Island could be over 500,000 years old and those on San Miguel Island and San Clemente Island could be over 1,000,000 years old. Detailed study of these and other high-terrace fossil localities on the Channel Islands can teach us much about the paleoceanography of the early and middle Pleistocene in southern California.

\section{Stratigraphic Associaton of Fossil LAND SNAILS AND MAMMOTHS ON THE CHANNEL IsLANDS}

As pointed out by LeVeque (2000), Cockerell had an early interest in malacology (both marine and terrestrial) and could very well have made this, rather than entomology, the main focus of his career. Despite his main focus on entomology for most of his career, he did in fact make contributions to the field of terrestrial malacology on the California Islands and island chains elsewhere. By the 1920s, he had done extensive work on the land snails of the islands of Madeira (Cockerell 1921a, 1921b, 1921c) and had found a new species of snail on Santa Catalina Island (Cockerell 1929).

In three papers resulting from his visits to San Miguel Island, Cockerell reported the presence of the land snail Helminthoglypta ayresiana (Fig. 7a) in both living and fossil form (Cockerell 1937b, 1938d, 1938e). Also in the 1937 paper, he reported finding fossil H. ayresiana specimens associated with secondary carbonates ("caliche") with a cylindrical form. We now recognize these features as carbonate rhizoliths, which Cockerell (1937b) correctly identified as forming around plant roots in carbonate aeolianites. Cockerell had previously seen similar features in the Madeira 
(a)
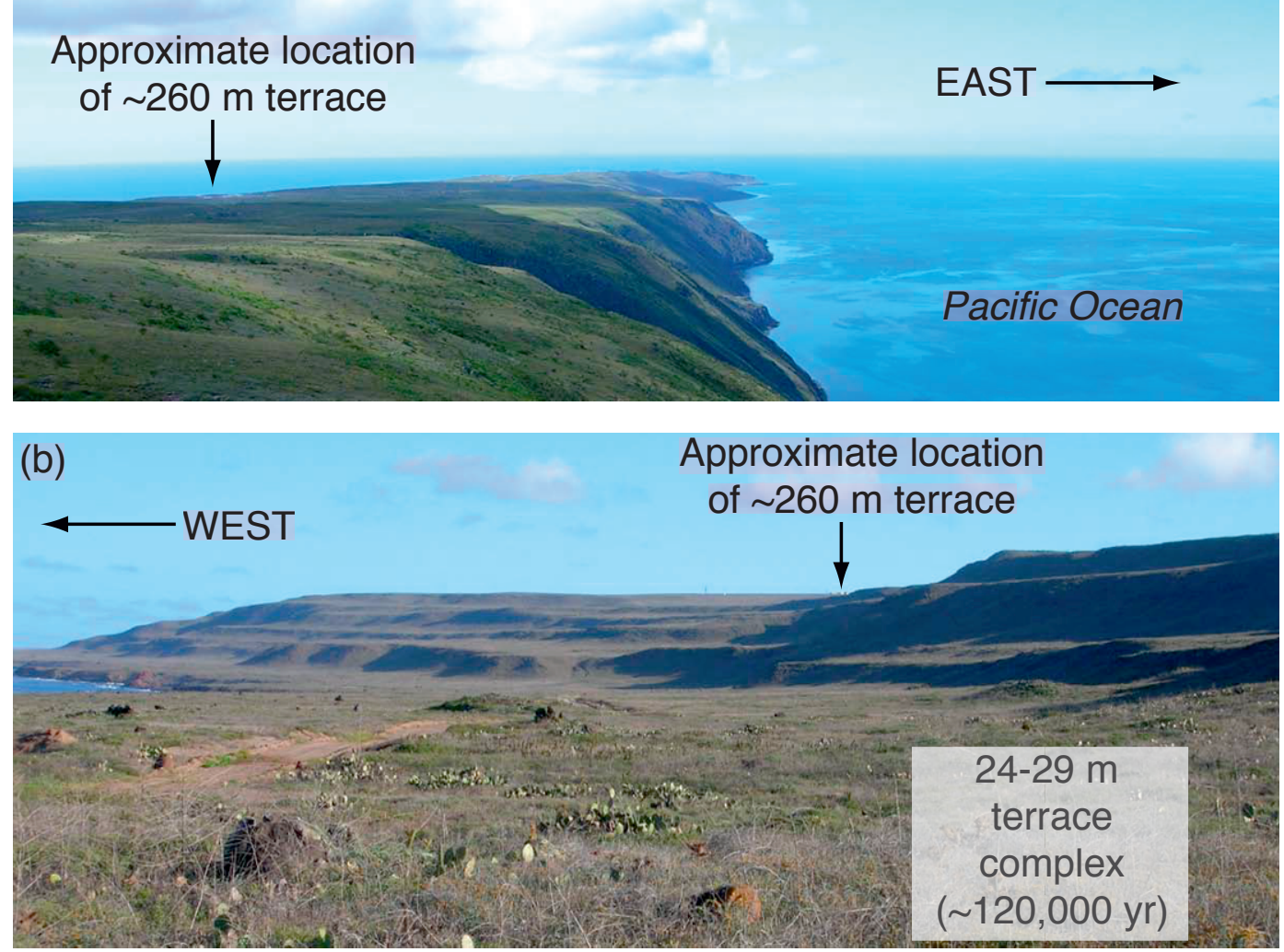

(c)

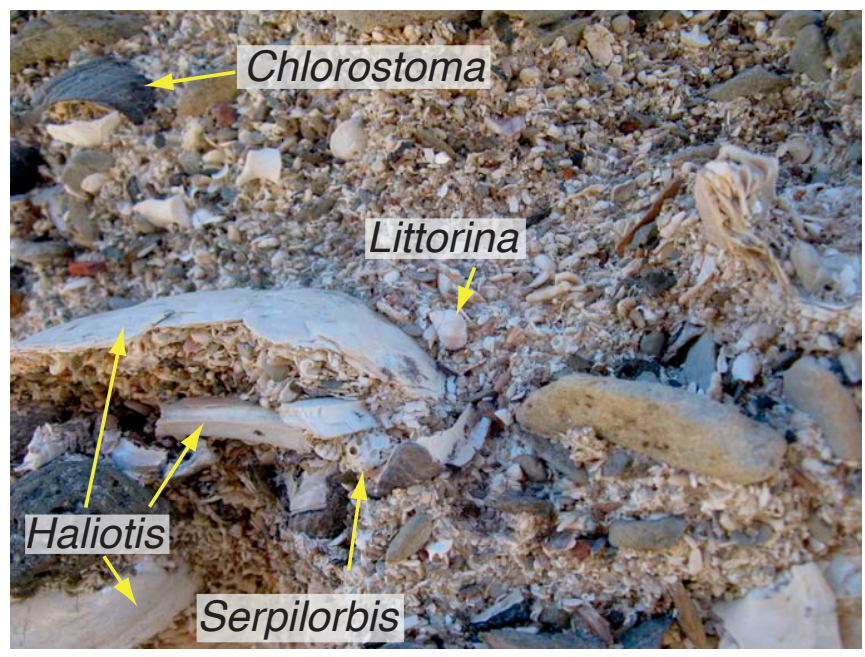

Fig. 6. (a) and (b) Photographs of marine terraces on San Clemente Island, California, showing probable location of the highest-elevation $(260 \mathrm{~m})$ and therefore oldest (thus far) fossil-bearing terrace deposits, discovered by T.D.A. Cockerell (see Cockerell 1939e). (c) Close-up of Pleistocene fossils in marine terrace deposit at $\sim 260 \mathrm{~m}$ elevation on San Clemente Island, California. All photographs are by D.R. Muhs. 

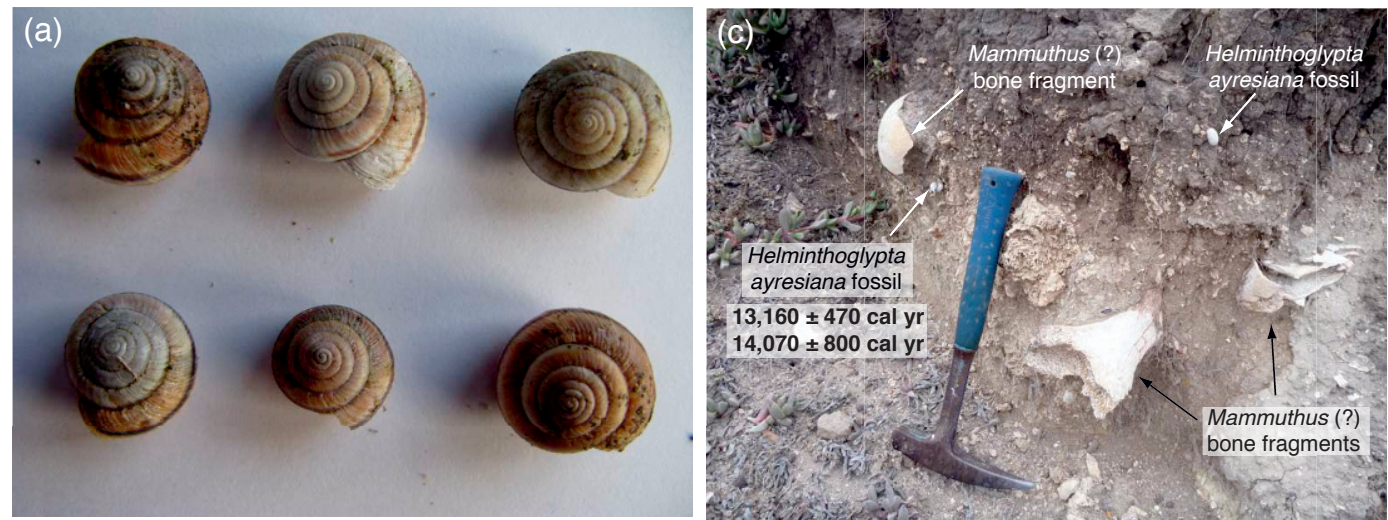

(b)

WEST $\longrightarrow$

(d)
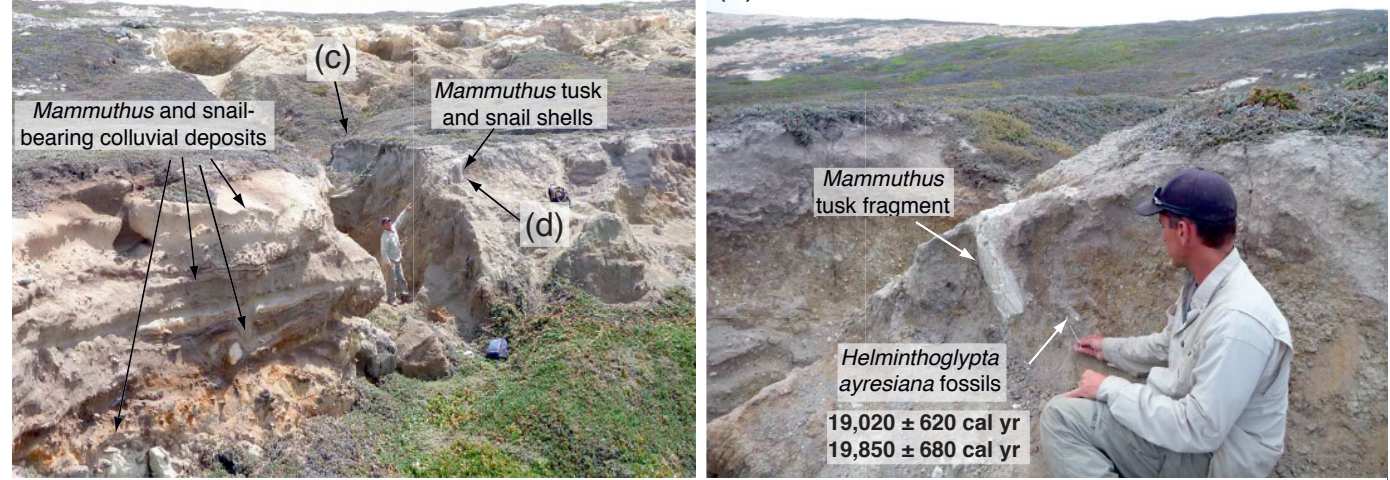

Fig. 7. (a) Modern specimens of the land snail Helminthoglypta ayresiana on San Miguel Island, as also reported by Cockerell (1937b, 1938d, 1938e). Geologic setting (b) and close-up photographs [(c) and (d)] of fossil Helminthoglypta ayresiana closely associated with mammoth remains, Running Springs area, San Miguel Island. Radiocarbon ages are from Pigati et al. (2017). All photographs are by D.R. Muhs.

Islands. In the 1937 paper, Cockerell noted that although the snails were fossils, he did not think they were as old as the fossil mammoth remains that had been found on San Miguel Island.

Less than a year later, however, Cockerell (1938e) again reported on fossil Helminthoglypta ayresiana on San Miguel Island, this time from a Pleistocene site to which he was taken by Herbert Lester. Lester and his family were living on San Miguel Island at this time (see Lester Roberti [2008] for memoirs of this period, including a short piece on Cockerell's visit to San Miguel Island). At this site, Lester had found mammoth remains that he and Cockerell examined in some detail. Cockerell (1938e) notes that snail shells were embedded with the mammoth remains. The focus of this paper was on the much smaller size of the fossil $H$. ayresiana compared to living specimens and the possibility that the Pleistocene speci- mens could therefore be a subspecies. What is also significant, however, is the fact that unlike his earlier (1937b) speculation that the fossil snails were not likely as old as fossil mammoths on San Miguel Island, here they were in clear stratigraphic association with the mammoth remains.

This second report (Cockerell 1938e) was an inspiration to later researchers, specifically because of the stratigraphic association of fossil land snails with mammoth bones. Fossil bone is notoriously difficult to date with radiocarbon methods, and many radiocarbon ages of bone are considered to be highly suspect (see review in Taylor 1992). In contrast, recent studies have shown that land snails, also once considered unsuitable material for radiocarbon dating, are actually quite reliable, once the species effect on retention of old, "dead" carbon (the "limestone effect") is understood (Pigati et al. 2010, 2013). Armed with the 
information that mammoth remains on the Channel Islands could be associated with fossil land snails, later researchers sought localities where stratigraphic studies with radiocarbon dating could be undertaken. Two recent papers resulted from these efforts. One paper provided the first stratigraphically controlled study of mammoth remains on San Miguel Island (Figs. 7b, c, d), confirming earlier conclusions (without stratigraphic control) that mammoths were present during the last glacial period, $\sim 20,000$ to 19,000 years ago (Pigati et al. 2017). The other study showed that mammoths were on Santa Rosa Island prior to $\sim 46,000$ years ago, or beyond the range of radiocarbon dating (Muhs et al. 2015). Awareness that mammoth remains could be associated with fossil land snails, first noted by Cockerell (1938e), has opened up the possibility of providing a means of reliable dating of mammoth remains elsewhere on the Channel Islands.

\section{ISLAND Biogeography, DisPERSAL MECHANISMS, AND ENDEMISM}

One of the most pertinent questions in island biogeography is how organisms reach islands, particularly remote ones. A related question is the origin and evolution of insular endemics. Cockerell, in his work on the Channel Islands, considered these questions in some of his summary papers on island life (Cockerell 1937c, 1938c, 1938d, 1939d, 1939f, 1940a). In his consideration of the origin of endemics on the California islands, Cockerell was of course limited by what was known of the geology of southern California in the late 1930s. Reed (1933) had just published his major work on the geology of California. In it he postulates the existence of ancient land masses that he refers to as "Anacapia" (including the northern Channel Islands and the western Santa Monica Mountains) and "Catalinia" (including the southern Channel Islands). Cockerell (1938d, p. 180) articulates his understanding of what the geological thinking was at the time:

Geologists suppose that during the Tertiary Epoch there was a land, which has been called Catalinia, extending from the northern islands southward, including the southern islands and the vicinity of San Pedro on the present mainland, and possibly going as far as Guadalupe Island, far out in the Pacific.
How much of this land persisted into the Pleistocene remains uncertain.

Cockerell (1939f, p. 311) elaborates on this concept in another paper a year later:

Thus connection with the mainland, at some remote period, must have occurred. Geologists have postulated that, as late as Miocene times at least (between about 17 and 37 million years ago), there existed a large land area, including all the present islands, which were then parts of mountain ranges. This land has been called Catalinia, and it is supposed that it included San Pedro Hill, familiar to mainland Californians, which looks very much like another island when seen from Santa Catalina.

From these comments, we can infer that Cockerell's interpretations of geologic history of the region (inferred to be primarily from Reed 1933) would include the idea that all the islands were connected to the mainland. Further, he infers from what is said that all the islands, both the northern and southern chains, were connected to each other. It is important to remember that at the time Reed wrote his monograph in 1933 and Cockerell inferred geologic history from it a few years later, geologic mapping in California was woefully incomplete (particularly on the Channel Islands), plate tectonic theory did not exist, radiometric dating did not exist, Quaternary sea level history was not understood, and the importance of the San Andreas Fault was not as fully appreciated as it is today.

The concept of land bridges between the islands and mainland in southern California held sway for a long time. Even as late as 1967, Weaver and Doerner (1967) proposed that there were connections between the northern Channel Islands and the mainland during the Oligocene, Pliocene, and Pleistocene. The principal argument for the supposed land bridge from the northern islands to the mainland during the Pleistocene is the presence of fossil mammoth remains on San Miguel Island, Santa Rosa Island, and Santa Cruz Island. The perception was that such a large organism could have gotten to these islands from the mainland only by foot, at some point or points in the Pleistocene, and that would have required a land bridge. The belief that a land bridge from the California mainland to the Channel Islands was required brought 
about some highly imaginative re-creations of Pleistocene paleogeography of the region, admirably summarized by Johnson (fig. 1 in Johnson 1978). Nevertheless, later work established that there was no geologic or geophysical evidence that such a land bridge existed (Junger and Johnson 1980, Wenner and Johnson 1980). Johnson (1978) identified the mechanism of mammoth arrival to the Channel Islands using analog behavior from modern African and Indian elephants: the animals got to the islands by swimming during periods of lowered sea level. These studies effectively debunked the entire concept of hypothesized land bridges from the California mainland to the Channel Islands in the Quaternary. Newer evidence from the longer-term geologic history of the region, summarized by Vedder and Howell (1980), eliminates the idea of preQuaternary land bridges as well.

However, the work cited above debunking the Quaternary (and earlier Tertiary) land bridges came decades after Cockerell's work. Cockerell cited Reed's (1933) work in a number of his papers and attempted to reconcile the geologic hypotheses proposed therein with what he observed in the biology of the islands. In his earlier paper summarizing the biology and geology of San Miguel Island, Cockerell (1938d) seems to have accepted the general thinking of the time that there must have been a land bridge between the mainland and the northern islands. In the same year, however, Cockerell (1938c) points out the differences between the snail faunas of the southern islands (Micrarionta and Xerarionta) and the northern islands (Helminthoglypta ayresiana only; no Micrarionta and Xerarionta). In his view, these faunal differences require that even if both island chains were connected to the mainland, then as a minimum, the northern islands and southern islands would have to have been separately connected to mainland California (in other words, two land bridges) in the most recent geologic time for snail genera divergence. In a paper published just a year later, as he considers dispersal mechanisms for island biota, Cockerell (1939d) seems even more skeptical of land bridges. Indeed, he independently reaches the same conclusion as Johnson (1978), Junger and Johnson (1980), and Wenner and Johnson (1980) about the unlikelihood of a mainlandto-island land bridge. Cockerell notes that one argument against land bridges is the lack, on the islands, of so many species found in [mainland] southern California. Cockerell (1939d, p. 102) expresses his skepticism for the land bridge concept as follows:

\section{In the first place, how were the islands popu- lated? Supposedly, originally, by ancient land connections, but it is noteworthy that many forms of life now common in Southern Cali- fornia, are totally lacking on the islands.}

In a paper on the botany of the Channel Islands, Cockerell (1937c, p. 123) points out that if there had been a recent connection of the islands to the mainland, many plants that might be expected to occur on the islands do not. In a later paper on Channel Islands insects, Cockerell (1940a) also notes that the insular endemics, at least among the bee populations of the Channel Islands, are all at the species level or below, with no endemic genera. This suggested to him that endemism of the bee population could not have been of very great antiquity.

By 1940, as described above, Cockerell had also studied the marine terrace fossil record at relatively high elevations on San Miguel Island and San Nicolas Island (at what he describes as the "tops" of the mesas on the islands), and San Clemente Island, at an altitude of $\sim 260 \mathrm{~m}$ (Cockerell 1938c, 1939e, 1940b). Cockerell (1939d, p. 102) states that

the Pleistocene marine beds on San Miguel and San Nicolas indicate almost complete submergence in some part of Pleistocene time[.]

In a later paper, he also states the following (Cockerell 1940b, p. 501):

We must conclude from these observations that during part of the Pleistocene the three islands referred to were nearly under water[.]

Cockerell's statement, referring to San Miguel Island, San Nicolas Island, and San Clemente Island, argues against significant land bridge connections. This is a novel line of reasoning (i.e., using marine terrace geomorphology at a time when little was known of Quaternary sea level history) and is a perceptive observation that challenges the land bridge hypothesis. We now know through detailed marine terrace mapping (Vedder and Norris 1963, Muhs et al. 2012 , 2014) that at least San Nicolas Island 
and likely San Miguel Island were almost certainly fully submerged at some point in the Pleistocene. They have been only slowly uplifting since that time, with no evidence of a subaerially exposed connection to the mainland.

From my careful reading of his papers, Cockerell seems to have made a genuine attempt to reconcile concepts about the geological evolution of southern California that were in vogue at the time into his own speculations about the origins of island species, particularly insular endemics. What is clear from his work and his comments, however, is that there were numerous inconsistencies that he perceived in the island biogeography which made the land bridge reconstructions untenable. Thus, with at least a healthy doubt of the land bridge mechanism for species dispersal to the Channel Islands, he offered other mechanisms for migration of plants and animals to the Channel Islands. These modes of biotic dispersal were succinctly reviewed in Cockerell's "recollections" paper on the Channel Islands (Cockerell 1939d) and his summary paper on the insects of the Channel Islands (Cockerell 1940a). Such dispersal processes include $(a)$ migration of species to the islands under their own power, by flight; $(b)$ transport of species by air currents; $(c)$ carrying of organisms to the islands by birds; and $(d)$ transport of organisms to the islands via floating objects.

Studies conducted since Cockerell's summary show support for the importance of these dispersal mechanisms in the Channel Islands. With regard to dispersal mechanism $b$ (transport of species by air currents), it might seem, at first consideration, to be a counterintuitive proposal, as winds in the Channel Islands region are dominantly from the northwest and the California mainland lies to the east. Nevertheless, several times each year, after a cold front passes across the Pacific Coast and a high-pressure cell settles in the Great Basin, winds in coastal southern California are dominantly from the east or northeast for a day to two days. Known as Santa Ana winds, these winds can be very strong and are certainly capable of transporting seeds or small insects that would otherwise be incapable of flight. Evidence from satellite imagery and soils on both the northern and southern Channel Islands indicates that Santa Ana winds are probably responsible for the delivery of min- eral particles from the California mainland to the islands (Muhs et al. 2007, 2008). Concerning dispersal mechanism $c$ (organisms carried to islands by birds), Cockerell (1939d) provides interesting examples from the California islands and makes an important point about the process of endemism. Cockerell (1939d) notes that there is a genus of slug (Binneya) found on Santa Barbara Island, San Nicolas Island, and Guadalupe Island. The species on Guadalupe Island, however, is distinct. Cockerell (1939d) points out that in the dry season, Binneya is covered with a sticky, mucus-like substance that protects it from desiccation. The same sticky mucus allows it to become attached to birds and thereby transported to a distant island. One can well imagine that such occurrences are not frequent, but Cockerell (1939d, p. 103) asserts that the rarity of such an event is precisely why a species evolves to be an insular endemic:

It is not surprising that actual proof of such transportation is rarely to be had; the event must be a very rare one, as otherwise the insular races, evolving under conditions of isolation, would be swamped by newcomers.

This is a critically important point with regard to the origin of insular endemics. Population of islands by these dispersal mechanisms must comprise rare events, because otherwise mainland species migrating to islands would surely dominate the island populations and separate species would never have had time to evolve independently. Mechanism $d$ (dispersal of organisms by floating objects) is essentially the equivalent of what Simpson (1940) called "sweepstakes" dispersal in his now-classic paper on the subject. Simpson (1940) noted that this mechanism, where chance transport of organisms to islands can occur by a variety of means, explains what would otherwise be rather baffling animal occurrences on distant islands. Wenner and Johnson (1980) noted that such a mechanism could explain the occurrence of the two salamander species that occur on the northern Channel Islands. They point out that salamanders can occupy partially decayed logs that, during floods, can be transported through mainland river valleys and out to sea. Another "floating object" that can transport organisms is watercraft of early human visitors to the islands (Wenner and Johnson 1980). Humans have been visiting the 
northern Channel Islands for at least the past $\sim 12,000$ years, in calibrated radiocarbon years (Erlandson et al. 2011). Thus, inadvertent transport of small organisms, hidden within the cargo of ocean-going early humans, has been a viable dispersal mechanism for at least the length of the Holocene.

\section{Cockerell's Role in the Establishment of Channel Islands National Monument}

Only 16 years after it was established in 1916, the National Park Service (NPS) was contacted by what was then the Bureau of Lighthouses about the possibility of transferring "certain island Lighthouse reservations off the Coast of California to the National Park Service" (Rhodes 1932). H.W. Rhodes, Superintendent of Lighthouses, was referring to the possibility of such a transfer for San Miguel Island, Anacapa Island, Santa Barbara Island, San Nicolas Island, and San Clemente Island. Both Dr. William Albert Setchell of the Department of Botany, University of California-Berkeley, and Dr. Joseph Grinnell, Museum of Vertebrate Zoology at the same university, wrote letters on 9 February 1933 and 10 February 1933, respectively, to Thomas C. Vint, Chief Landscape Architect, National Park Service, San Francisco, California, voicing their strong support for acquisition of the Channel Islands by the National Park Service (Grinnell 1933, Setchell 1933).

Over the next few years, little activity seems to have taken place with regard to transferring the islands to the National Park Service, at least based on available records at the National Archives in San Bruno, California. However, in her comprehensive book on the history of San Miguel Island, historian Lois Roberts states that in 1937, Rhodes again contacted the National Park Service about transferring the islands over to their jurisdiction (Roberts 1991). The National Park Service (NPS) agreed to send NPS personnel out to survey the islands. Roberts (1991) has a brief summary of the events that followed, indicating that Dr. H.C. Bryant, Assistant Director of the National Park Service, made a visit to some of the islands and was not favorably impressed. Roberts further indicates that subsequent events are not entirely clear, but hypothesizes that T.D.A. Cockerell, who had already been working on the islands, appar- ently was influential in reversing the NPS assessment of the suitability of the islands for inclusion into a national monument.

Because of uncertainties in this sequence of events, it seemed worthwhile to test the hypothesis of Roberts (1991) concerning Cockerell's role in the establishment of Channel Islands National Monument by investigating the surviving records from this time period. One source included the collection of papers, letters, photographs, and other materials of Cockerell compiled by Dr. William A. Weber (retired), University of Colorado, and archived in the Special Collections and Archives section of the Norlin Library at the University of Colorado-Boulder. The other source was the collection of letters and documents regarding the business of parks in the western USA in the National Archives-San Bruno. With the documents and letters examined from these two sources, a fairly clear picture emerges of the likely sequence of events in the establishment of Channel Islands National Monument.

After the correspondence between Rhodes (Lighthouse Bureau), Vint (NPS), and Setchell and Grinnell (University of California-Berkeley) of 1932-1933, the next earliest document found is a letter dated 19 July 1937 from A.E. Demaray, Associate Director of the NPS, to the Commandant of the U.S. Coast Guard in San Francisco, advising him that the NPS would be sending two or three park officials to California "to look over this situation" with regard to the possible transfer of islands to the NPS (Demaray 1937). Shortly thereafter, on 23 July 1937, Arno B. Cammerer (Fig. 8), who by then was Director of the NPS, wrote to the Commissioner of Lighthouses (Cammerer 1937):

Dr. H.C. Bryant, Assistant Director of this Service, is leaving in a few days for a field trip through some of the western parks. He will be in San Francisco during the first week in September and expects to communicate with your local representative in that city in connection with his investigation of the Channel Islands, which include Santa Barbara and Anacapa Islands. I shall appreciate the courtesy if you will notify your local representative of Dr. Bryant's expected visit.

As stated in our letter of May 21, decision has been made to negotiate the transfer of the Government-owned island [sic] in this group to the Department of the Interior for 
(a)

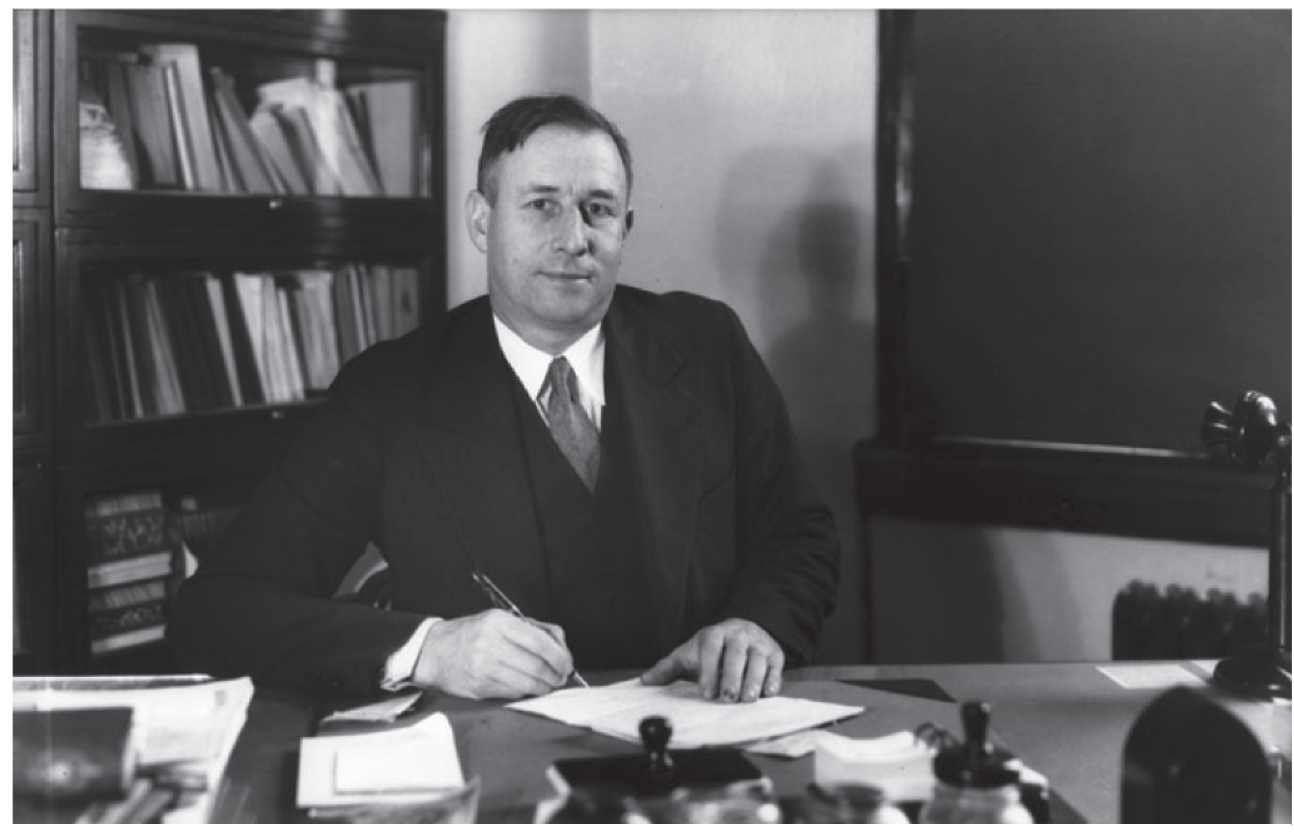

(b)

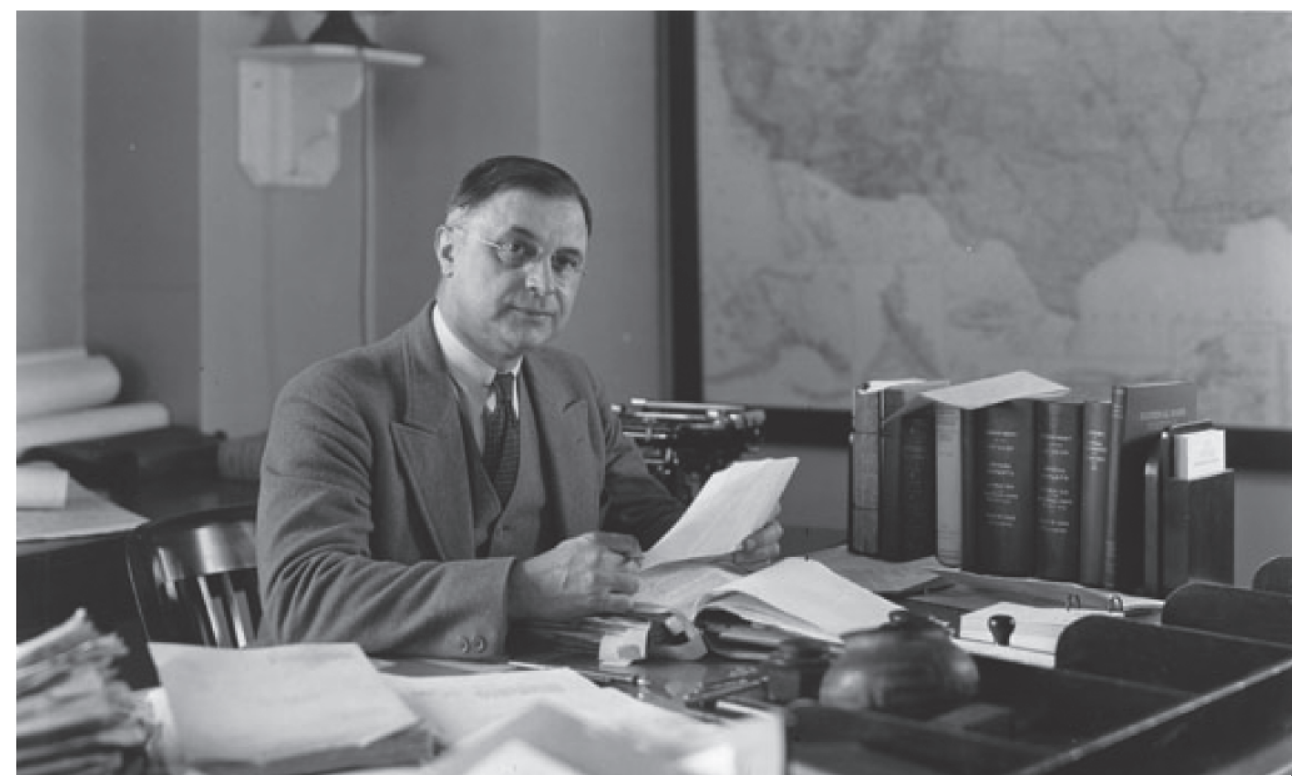

Fig. 8. Photographs of two National Park Service officials who relied on T.D.A. Cockerell's scientific expertise in making the recommendation to create Channel Islands National Monument in 1938: (a) Harold C. Bryant, Assistant Director (NPS photograph taken 1 February 1933 by George A. Grant); (b) Arno B. Cammerer, Director (NPS photograph \#HPC_000181, taken 31 January 1933 by George A. Grant).

national monument purposes, provided there could be included a sufficient variety of land to accomplish certain objectives regarding protection, recreation, and administration. We are not in a position to make a definite statement in this regard at this time, but immedi- ately upon Dr. Bryant's return this fall, we shall advise you definitely whether the islands are desirable for national monument purposes.

This letter is significant for 3 reasons. One is that it is apparent that despite the several- 
year gap between the initial contact of the Lighthouse Bureau with the NPS about acquiring the islands, the NPS is indeed seriously interested in the islands. On the other hand, Cammerer is also noncommittal; it is clear from his statement in the second paragraph that the proposal of island transfer is conditional. Finally, it is also seems likely that Cammerer's decision may be based to a great extent on what he hears from NPS Assistant Director H.C. Bryant (Fig. 8). Thus, Bryant's impressions after his visit to the islands are critical to what follows.

On 20 September 1937, Bryant and two other NPS officials (Bernard F. Manbey, Acting Assistant Regional Director, Region IV; and Lawrence F. Cook, Deputy Chief Forester, Region IV) took a one-day trip to visit the Channel Islands. The events of that day are outlined in the itinerary appended to Bryant's report submitted to the Director of the NPS on 27 November 1937 (Bryant 1937a). The three left Santa Barbara at 7:30 AM, on the Coast Guard boat Hermes, landed at Prisoners Harbor on Santa Cruz Island, and apparently spent most of the morning on a brief tour with landowner Edwin L. Stanton and his wife, Evelyn. Returning to the boat, the party traveled to Anacapa Island, decided it "was too precarious to land" and proceeded to Santa Barbara Island, a journey that took most of the afternoon. As with Anacapa Island, the group decided it was too dangerous to land and looked the island over from the boat. Finally, the party returned to Santa Barbara, arriving about 10:00 PM, and apparently experienced a rough trip, with two members of the party getting seasick.

All three members of the NPS party on the 20 September 1937 voyage wrote reports on their visit to the islands. A cover letter dated 19 October 1937 to NPS Director Cammerer from Frank A. Kittredge, Director of Region IV, stated that two copies of the report by Manbey were enclosed (Kittredge 1937). Despite repeated searches at the National Archives-San Bruno, this report could not be found, nor was it with Bryant's report, where it was supposedly appended. Despite this, it is possible to infer the conclusions of Manbey's report from other data, discussed below. Cook submitted his report a day later, 20 October 1937, in a letter to Director Cammerer of the NPS, copied to Bryant. In it he states the following (Cook 1937):
Only a very superficial inspection was possible, and the only island actually visited was Santa Cruz which is entirely privately owned. Several of the other islands were examined from the boat with field glasses.

None of the islands now owned by the Government appeared to me to be qualified or desirable for National Park status, either for conservation of national values or for recreation use.

One day after this (21 October 1937), Bryant wrote a letter to the Regional Director of Region IV, but with the note: "Attention: Mr. Mamby [sic]" (Bryant 1937b). It is not certain from the heading whether this letter was intended for both the Regional Director and the Acting Assistant Regional Director (Manbey, who it is assumed was the intended recipient stated as "Mamby"). From the text of the letter, it appears that Manbey was indeed intended to read it in any case:

Reference is made to the investigation of the Santa Barbara Islands of the past summer. I am now getting together a draft of a report and am in need of photographs and a report from you.

You will be interested to know that talks with Dr. J. Grinnell and Dr. Loye Miller indicate that scientists urge strongly that these two lesser islands be accepted in order to prevent their going into private ownership. Both men called attention to the large number of sea birds nesting on these islands, to the fact that the California sea lion utilizes Anacapa and to the fact that a sample of the fauna and flora of the Channel Islands should be retained in Government hands and given careful protection. I am told that Prof. T.D.A. Cockerell of the University of Colorado has been making a careful biological survey of the whole island group. I have written him to secure his opinion.

Even though admittedly we are taking a leftover, we have to acknowledge it is all that can be obtained at this time and that from a scientific viewpoint retention under Government control would be the best method of assuring proper protection to plant and animal life. National monuments are created largely to furnish protection and to me this is the most apparent need at the present time. You will see, therefore, that I am inclined to recommend that these two islands be accepted from the Lighthouse Service.

Please let me have copies of the photographs you took and let me have your recommendation as to action. 
This letter indicates that (1) Bryant had not yet made up his mind, but was tending toward a positive recommendation about acquiring the islands; (2) he valued the opinions of scientists, having already received some thoughts (from Grinnell and Miller) and was seeking an additional opinion (from Cockerell); and (3) he perceived Manbey to have a negative opinion of the islands, based on what appears to be his persuasive tone. The interpretation of Manbey being negative about the islands is borne out by two handwritten notes found on NPS letters at the National Archives in San Bruno, California. The first of these is a letter from NPS Associate Director Arthur E. Demaray to the Commissioner of the Bureau of Lighthouses, dated 29 October 1937 (Demaray 1937):

\begin{abstract}
Sufficient data has been received to support our decision to negotiate the transfer of Santa Barbara and Anacapa Islands to the Department of the Interior for national monument purposes. We are preparing a proclamation to establish these two islands as the Channel Islands National Monument, reserving in the proclamation that portion of Anacapa Island desired by your bureau as indicated in your letter of March 12. The proclamation will be cleared through the Department of Commerce before it is transmitted to the President for his consideration.
\end{abstract}

This letter was copied to Region IV, Dr. Bryant, and Mr. Little. There is a handwritten note on it addressed to "Mr. Kittredge" [presumably Frank A. Kittredge, Regional Director of Region IV at this time]:

Cook and I in our reports considered these lacked NPS calibre [sic]—so did Dr. Bryant. Later he seems to have reversed himself.

Because Manbey was in the Region IV office and had accompanied Cook and Bryant to the islands, there is little doubt that this handwritten note to Kittredge is from Manbey. In another letter, dated 24 January 1938, sent to a Mr. C.S. Race, of Los Angeles, California, Demaray (1938) states:

By reference from Secretary Ickes, your letter of January 18 that was co-signed by Mr. M.N. Platt, regarding the proposal to establish Santa Barbara Island, off the southern California coast, as a national monument, has been referred to this Service for reply.
For some time, this Service has had under consideration a proposal to establish the Channel Islands National Monument to include certain channel [sic] islands in Federal ownership off the coast of southern California. These islands were investigated by representatives of this Service who recommended them for inclusion within the national park system because of the need for conservation of the unique biological and geological features found there.

This letter was also copied to the Region IV office. On this letter, a red pencil was used to underline the last sentence quoted above, with a handwritten note, also in red pencil:

Dr. Bryant Cook Manbey made last investigation. Cook and I did NOT [emphasis his] recommend inclusion.

Again, there is little doubt that this handwritten note was made by Manbey. Thus, although Manbey's report could not be found, the notes on these two letters indicate that Manbey was strongly opposed to including the islands under consideration for NPS status.

As noted above, Bryant stated his intention to contact Cockerell regarding the islands in his letter of 21 October 1937. Bryant and Cockerell knew each other from previous communications. In the Special Collections section of the University of Colorado-Boulder library, I found letters from 1933 indicating that the two had corresponded about the biology of Rocky Mountain National Park and clearly had a deep respect for one another. Presumably, from what he said in his letter of 21 October 1937, Bryant wrote a letter to Cockerell about the islands, although a copy of this letter could not be found either at the National Archives or the University of Colorado. Nevertheless, Cockerell (1937d) responded to Bryant in a letter dated 28 October 1937:

\section{Dear Mr. Bryant:}

I am indeed glad to hear from you about the islands. I enclose (but should like returnedno great hurry) a paper I wrote, which sets forth some of the principal points of interest. On August 25 I sent a copy of this paper to Cattell, suggesting that it might go in the Scientific Monthly. For some reason which I cannot explain I have heard nothing, although I have written since to ask what became of the paper. I wrote this paper primarily for the purpose of having something I could hand to people to explain why the islands 
were considered of unusual interest. I do not know whether there is any agency which would get out a bulletin on the subject if I would prepare it. Even a short statement of 3 or 4 pages might be valuable at this juncture-something you could put in a letter. I hope eventually, if I can keep going another 5 years or so, to make a book on the subject combining the results of many workers, and showing, as far as possible, what the islands could teach us. If this could be nicely illustrated, I believe it would be of general interest.

Although it is true that many zoologists and botanists have written on the biota of the islands, no one has assembled all the results together, and it is evident that few, even of the scientific men of California have any appreciation of the great value of the subject for the understanding of evolution and the biological phenomena. The more I work at the subject, the more impressed I become with the extraordinary importance of these islands for natural history studies.

Having said this much, you can well believe that I am anxious to see the islands publicly owned, and preferably in the hands of the Park Service. I do not see why the Navy should hold them, doing nothing with them. In case of war or the threat of war, of course, the Navy would have a free hand to do whatever was necessary, on any of the islands, to defend the country."

The manuscript that Cockerell was referring to was entitled "San Miguel Island," and was published shortly thereafter (Cockerell 1938d), without modification from what Cockerell sent to Bryant, in Scientific Monthly, volume 46, pages 180-187. The journal Scientific Monthly was eventually absorbed by the journal Science, one of the most prestigious journals in the scientific world today. Cockerell's submitted manuscript likely was, as was his practice, handwritten, but Bryant apparently had it typed in the NPS offices in Washington, DC, and included this typed version and Cockerell's letter in his final report.

Shortly thereafter, Bryant wrote back to Cockerell in a letter dated 8 November 1937 (Bryant 1937c):

\section{Dear Professor Cockerell:}

I wish to express my sincere appreciation for the excellent report on the Santa Barbara Islands which you so kindly furnished with your letter of October 28. This article contained a great deal of very helpful general information on the islands which we did not have. There is returned your original manuscript together with two typewritten copies which were made in this office.

The decision has been made to ask for the transfer of Anacapa and Santa Barbara Islands to the National Park Service due to the fact that scientists have unanimously requested this action. The Lighthouse Service has stipulated that a small area surrounding each island should remain under their administrative jurisdiction for safeguarding against accidents.

From this letter and from his inclusion of Cockerell's letter and manuscript in his final report to the NPS, it is clear that Bryant valued Cockerell's opinion in his consideration of what to recommend to the NPS Director. Bryant submitted his report to NPS Director Cammerer on 27 November 1937, based on the date of the cover letter that was archived. Bryant's submission included the basic report (presumably written by Bryant), an excerpt on birds of the Channel Islands written in 1917 by Alfred B. Howell of the Cooper Ornithological Club (Howell 1917), an excerpt from Geology of California written by Ralph D. Reed (Reed 1933) and published by the American Association of Petroleum Geologists, an itinerary, and four appended items: (1) Manbey's report; (2) Cook's report; (3) Cockerell's letter of 28 October 1937; and (4) Cockerell's manuscript on San Miguel Island that was ultimately published in Scientific Monthly in 1938.

Shortly after Bryant's report was submitted, NPS Director Arno B. Cammerer sent a letter (7 February 1938) to Harold L. Ickes, Secretary of the Department of the Interior, proposing the establishment of Channel Islands National Monument (Cammerer 1938). In this letter, Cammerer states:

The proposed Channel Islands National Monument was one of those which met with your approval during our conference in your office on October 20, 1937. The important factor here is the opportunity to preserve important scientific values needing Government protection. Here exist over 80 endemic flowering plants, about 30 endemic mammals or birds, and 15 land mollusks. These endemics are of two types. The relict type may have been more widely distributed in former times, but now survives only on these islands. The true island endemics acquired their special characteristics on the islands. 
Fossils ranging from marine invertebrates to Pleistocene elephants and fossil trees have been found on the islands.

... Attached are drafts of letters for your signature, transmitting a proposed proclamation to establish the Channel Islands National Monument under authority of the Act of June 8, 1906. Because the Department of Commerce now has jurisdiction of these islands, the proclamation should first be submitted to that Department for approval and then routed through regular channels for consideration by the President.

The significant characteristics of the islands listed here by Cammerer (endemic flowering plants, endemic mammals and birds, endemic land mollusks, Pleistocene elephants, fossil trees) are all taken directly from Cockerell's (1938d) paper in Scientific Monthly on San Miguel Island. This indicates that Cammerer considered the island characteristics that Cockerell outlined to be the most critical items for justification of national monument designation to the Secretary of the Department of the Interior. Less than two weeks later, Bryant wrote again to Cockerell in a letter dated 17 February 1938, confirming the plans in progress to establish Channel Islands National Monument (Bryant 1938a):

You will be interested to know that the National Park Service is moving to have Santa Barbara and Anacapa Islands transferred from the Lighthouse Service and to have them proclaimed a national monument. Until some better scheme is devised, we believe this to be the best means of giving suitable protections to these interesting rocky islands.

Many thanks for the papers which you sent. One set has been carefully filed with all of our material on the Santa Barbara Islands.

A month later, on 17 March 1938, Secretary of the Department of the Interior Harold L. Ickes wrote to the Secretary of the Department of Commerce, enclosing a letter to the President and a form of proclamation establishing Channel Islands National Monument. In this letter, he also stated that if the enclosed papers were satisfactory, they should be forwarded to the President for his consideration (Ickes 1938). Finally, on 26 April 1938, President Franklin D. Roosevelt signed a proclamation establishing Channel Islands National
Monument, including Anacapa Island and Santa Barbara Island.

It is interesting to note that even after establishment of Channel Islands National Monument, Cockerell's influence is apparent in further correspondence between U.S. government officials. For example, at some date apparently in August 1938, Acting Secretary of the Interior E.K. Burlew wrote to the Secretary of the Navy (Burlew 1938):

The proclamation establishing the Channel Islands National Monument, consisting of the major portions of two small islands off the southwest coast of California, was signed on April 26. These two islands, in common with most of the other Channel Islands, have much of scientific value requiring governmental protection. A number of fossils, ranging from marine invertebrates to the Pleistocene elephants and fossil trees have been found thereon. More than 80 endemic flowering plants and some 30 endemic mammals or birds, and 18 land mollusks add further to the scientific importance of these islands.

Again, the natural features of the islands described in this letter come directly from Cockerell's recently published (1938d) paper on San Miguel Island in the Scientific Monthly. Early in the following year (5 January 1939), NPS Director Arno B. Cammerer wrote to the Director of NPS Region IV about a proposed new survey of the islands (Cammerer 1939):

Recent correspondence from the Navy Department, copy of which is enclosed, indicates the advisability of making a preliminary reconnaissance of biological values in the newly created Channel Islands National Monument. You will note by reference to the letter that this Service is also interested in the possibilities of San Miguel Island.

.. . Consultation with Drs. Mason and Grinnell of the University of California and with scientists of the Santa Barbara Museum will doubtless be of material assistance to you previous to examination of the islands. They can probably supply you with several references. Two recent references have come to our attention as follows:

Cockerell, T.D.A. The Botany of the California Islands. Torreya 37:117-123, Nov.-Dec., 1937.

San Miguel Island, California. Scientific Monthly, 46:180-187, Feb., 1938 
You will no doubt find the U.S. Coast and Geodetic Survey charts to be most helpful in this work. Chart No. 5202, Point Fermin to Point Conception, includes the three islands upon which information is desired."

Thus, it would appear that by this time, Cockerell was firmly established in the minds of the NPS leaders as one of the scientific authorities on the Channel Islands. Further, it is clear that the NPS was interested in continuing work that Cockerell was undertaking on the Channel Islands. In the collections at the University of Colorado, the latest letter from Bryant to Cockerell is dated 20 September 1938 and includes these passages (Bryant 1938b):

Your letter of September 7 brings the information that you were able to visit five of the Santa Barbara Islands during the past summer. Your report on the fauna must surely be progressing with such good fortune coming your way. We have noted with interest the significant discovery of marine pleistocene [sic] on the top of the mesa both on San Miguel and San Nicolas.

We are glad to have your comment relative to the statement made in the press release on the establishing of Channel Islands National Monument. Care will be taken not to give out misleading information.

It is true that some effort has been made to secure additional islands. To really make it a worth while area, Santa Cruz should be added. This seems impossible at the present time with a new owner who is thoroughly interested in a commercial venture. Recent attempts to get the Navy Department to cede either San Miguel or San Nicolas, or both, to the National Park Service have been unsuccessful. The suggestion is made that San Miguel may not be developed immediately and that, therefore, its biological resources can be administered intact. We hope that with the years some additions may be made to this initial area.

We shall appreciate your continuing to keep us informed on new finds in this area.

Neither Cockerell's letter of 7 September 1938 nor his comment concerning the press release on establishing the national monument could be found in the collections at either the University of Colorado or the National Archives. From Bryant's letter above, however, we can infer that Cockerell either recommended or at least inquired about the possibility of including other islands within Channel Islands National Monument. Bryant's comments about this in response in the third paragraph of his letter to Cockerell are a bittersweet foreshadowing of events to come. Both San Miguel Island and the eastern part of Santa Cruz Island did indeed become part of what was to be Channel Islands National Park in 1980. Sadly however, Cockerell, who passed away in 1948, and Bryant, who passed away in 1968, would not live to see the establishment of the park with these islands.

It is interesting to consider Bryant's background in the context of how he helped make a decision about whether or not to recommend the Channel Islands for national monument status. Bryant was a zoologist by training: he received a B.S. degree in zoology and ornithology from Pomona College, and M.S. and $\mathrm{PhD}$ degrees in zoology from the University of California at Berkeley (Danz 2000). Bryant would have conducted his own independent research during his college career, at the very least for his $\mathrm{PhD}$ dissertation. As a consequence, he would have been well acquainted with the time-tested reliability of the scientific method, the significance of research in understanding the evolution of the natural world, and the importance of peer-reviewed publication in establishing scientific credibility. Thus, it is not surprising that in making a decision about whether or not to consider the Channel Islands for monument status, he sought the counsel of established scientists who were actively working on the islands, particularly T.D.A. Cockerell. As discussed earlier, Bryant and Cockerell had corresponded about the biology of Rocky Mountain National Park in 1933, based on letters archived at the University of Colorado. By 1933, Cockerell had already published hundreds of papers (Weber 1965) and was a well-established and respected biologist with an international reputation. Bryant was surely aware of this, and thus when he learned Cockerell had been working on the Channel Islands at the same time the NPS was considering the islands for monument status, it was logical that he would seek Cockerell's opinion on the matter.

One of the interesting ironies of the history of establishment of Channel Islands National Monument is that the two islands that yielded information with the most direct influence on the decision-making process were not even 
under serious consideration for NPS administration at the time. The only island that the NPS Bryant-Cook-Manbey expedition of 20 September 1937 actually set foot on (and then only for a few hours) was Santa Cruz Island. This island was privately owned by the Stanton family and was not under consideration for national park or national monument status in 1937. The Cockerell (1938d) paper in the Scientific Monthly that was so influential in the decision-making process was clearly read and referenced by NPS Assistant Director Bryant, NPS Director Cammerer, and Acting Secretary of the Department of the Interior Burlew. This paper dealt solely with the natural history of San Miguel Island, which was not under consideration for national monument status at this time either. It is clear from Bryant's letter to Cockerell on 20 September 1938 that he (Bryant) had hopes that San Miguel Island could one day be a part of Channel Islands National Monument, but there was certainly no guarantee of this at the time the two men corresponded.

The interpretation of the surviving documents made here is that it was the foresight, patience, and scientific expertise of both men-Cockerell and Bryant-that brought about the successful establishment of Channel Islands National Monument. Although Roberts (1991) hypothesizes that Bryant was not favorably disposed toward establishing Channel Islands National Monument and that Cockerell "turned the tide," it was really both men who should be given credit for establishing the monument. Had Channel Islands National Monument not been established, one can only speculate whether Channel Islands National Park ever would have been established. Either way, both Cockerell and Bryant set the stage in the 1930s for establishing what is now one of the nation's most beautiful national parks.

\section{Conclusions}

T.D.A. Cockerell was an extraordinary scientist who was fascinated with islands worldwide while (ironically) spending the majority of his career at a landlocked university in Colorado. He made important contributions to the entomology of the California islands, particularly with regard to identifying new species of bees that constitute significant percentages of the total number of taxa found on the islands. Cockerell was among the first to study the marine terrace deposits on 3 of the islands and showed that the fossils in these sediments not only contain important records of past oceanographic conditions, but also provide evidence that the islands were largely submerged at the time. While studying the marine invertebrate communities of the region, Cockerell also pointed out that the Channel Islands are close to what is now recognized as a major faunal provincial boundary, at Point Conception, California. It is at this point where the cold California Current and the warm Inshore Countercurrent meet. Cockerell proposed that a diverse faunal composition, with northwardranging and southward-ranging species, should be found on the Channel Islands. Documentation of the modern species compositions of these communities establishes that he was correct. Cockerell was the first to observe that fossil mammoth remains on the Channel Islands were in close stratigraphic association with fossil land snails. This observation of his, combined with the later advent of successful radiocarbon dating of land snails, provides us with a new method by which to develop the chronology of mammoth presence on the Channel Islands.

As an assistant to Alfred Russel Wallace, Cockerell learned many of the principles of island biogeography early in his career. In some of his inferred skepticism about land bridges from the Channel Islands to each other and to the mainland, Cockerell enumerated alternative dispersal mechanisms by which organisms could reach the islands and provided thoughts on how the rare occurrence of such processes explain why insular endemics develop.

Finally, Cockerell's highly productive style proved timely when the National Park Service was considering two of the Channel Islands for national monument status. Cockerell had already developed a professional relationship with then-Assistant Director Harold C. Bryant. Thus, it was Cockerell's advice that Bryant sought when he was considering what to recommend to NPS Director Arno B. Cammerer regarding the Channel Islands. A manuscript on San Miguel Island that Cockerell eventually published in Science Monthly, along with Cockerell's recommendations, overrode two negative opinions of NPS personnel, and Channel Islands National Monument was 
created in 1938. The creation of this national monument, despite the initial negative field reports, demonstrates how one enlightened NPS official (Harold C. Bryant) seeking the opinion of one trusted scientist (T.D.A. Cockerell) can make a difference. Four decades later (5 March 1980), then-President Jimmy Carter signed into law (Public Law 96-199) the creation of Channel Islands National Park, which states (Title II, section 201),

.... there is hereby established the Channel Islands National Park, the boundaries of which shall include San Miguel and Prince Islands, Santa Rosa, Santa Cruz, Anacapa, and Santa Barbara Islands.

\section{ACKNOWLEDGMENTS}

It is a pleasure to thank the many people who helped me with this paper. The study was supported by the Climate and Land Use Change Program of the U.S. Geological Survey. Retired University of Colorado professor Dr. William A. Weber, who knew Cockerell personally, took time to give me his thoughts about Cockerell, provided valuable materials on Cockerell's life, read an earlier version of the paper, and gave me comments that improved it. Personnel at the Special Collections unit at the Norlin Library, University of Colorado-Boulder, gave me access to the Cockerell collections that had been put together by Bill Weber. For these courtesies, I thank Sean Babbs, Cheryl Koelling, Jennifer Sanchez, Barbara Ann Losoff, and David Hays. Bill Greene of the National Archives-San Bruno kindly gave me access to historic National Park Service documents that helped put the story of Channel Islands National Monument together. I thank my good friend and colleague Lindsey Groves of the Malacology Section, Natural History Museum of Los Angeles County, who thoughtfully provided a list of the modern marine invertebrate taxa that have been documented on San Nicolas Island. National Park Service personnel at Channel Islands National Park, particularly Laura Kirn and Kate Faulkner, encouraged the writing of this paper, which I appreciate. I am grateful for the comments of editor Mike Glassow (University of California, Santa Barbara) and two anonymous journal reviewers. Bob Thompson and Janet Slate, U.S. Geological Survey (Denver, CO), also read an earlier version of the paper and made helpful comments for its improvement.

\section{Literature Cited}

Abbott, D.F., and E.C. Haderlie. 1980. Prosobranchia: marine snails. Pages 230-307 in R.H. Morris, D.P. Abbott, and E.C. Haderlie, editors, Intertidal invertebrates of California. Stanford University Press, Stanford, CA.

Аввотт, R.T. 1974. American seashells: the marine Mollusca of the Atlantic and Pacific coasts of North America. 2nd edition. Van Nostrand Reinhold Company, New York, NY.

Belanger, C.L., D. Jablonski, K. Roy, S.K. Berke, A.Z. KRUG, AND J.W. Valentine. 2012. Global environmental predictors of benthic marine biogeographic structure. Proceedings of the National Academy of Sciences 109:14046-14051.

BRyant, H.C. 1937a. Report on proposed Channel Islands National Monument, 20 September 1937. RG 79, Records of the National Park Service Western Region, Regional Director, San Francisco, CA; National Archives, San Bruno, California, Central Decimal Site Files, 1932-53, 9NS-S accession number 079-89-001, Boxes 14 and 15.

Bryant, H.C. 1937b. Letter of 21 October 1937 from H.C. Bryant, Assistant Director, National Park Service to National Park Service Region IV Director. RG 79, Records of the National Park Service Western Region, Regional Director, San Francisco, CA; National Archives, San Bruno, California, Central Decimal Site Files, 1932-53, 9NS-S accession number 07989-001, Boxes 14 and 15.

Bryant, H.C. 1937c. Letter of 8 November 1937 from H.C. Bryant, Assistant Director, National Park Service to Professor T.D.A. Cockerell, University of Colorado, Boulder. Special Collections and Archives, University of Colorado, Boulder Library, Cockerell Collection, Box 3, Folder 64.

Bryant, H.C. 1938a. Letter of 17 February 1938 from H.C. Bryant, Assistant Director, National Park Service to Professor T.D.A. Cockerell, University of Colorado, Boulder. Special Collections and Archives, University of Colorado, Boulder Library, Cockerell Collection, Box 3, Folder 64.

BRyant, H.C. 1938b. Letter of 20 September 1938 from H.C. Bryant, Assistant Director, National Park Service to Professor T.D.A. Cockerell, University of Colorado, Boulder. Special Collections and Archives, University of Colorado, Boulder Library, Cockerell Collection, Box 3, Folder 64.

Burlew, E.K. 1938. Letter of August, 1938 from E.K. Burlew, Acting Secretary of the Department of the Interior to Secretary of the Navy. RG 79, Records of the National Park Service Western Region, Regional Director, San Francisco, CA; National Archives, San Bruno, California, Central Decimal Site Files, 1932-53, 9NS-S accession number 079-89-001, Boxes 14 and 15. Cammerer, A.B. 1937. Letter of 23 July 1937 from A.B. Cammerer, Director of National Park Service, to Commissioner of Lighthouses, Washington, D.C. RG 79, Records of the National Park Service Western Region, Regional Director, San Francisco, CA; National Archives, San Bruno, California, Central Decimal Site Files, 1932-53, 9NS-S accession number 079-89-001, Boxes 14 and 15 .

Cammerer, A.B. 1938. Letter of 7 February 1938 from A.B. Cammerer, Director of National Park Service to 
Secretary of the Interior, Washington, D.C. RG 79, Records of the National Park Service Western Region, Regional Director, San Francisco, CA; National Archives, San Bruno, California, Central Decimal Site Files, 1932-53, 9NS-S accession number 07989-001, Boxes 14 and 15.

Cammerer, A.B. 1939. Letter of 5 January 1939 from A.B. Cammerer, Director of National Park Service to National Park Service, Region IV Director. RG 79, Records of the National Park Service Western Region, Regional Director, San Francisco, CA; National Archives, San Bruno, California, Central Decimal Site Files, 1932-53, 9NS-S accession number 079-89-001, Boxes 14 and 15.

Coan, E.V., P.V. Scott, And F.R. Bernard. 2000. Bivalve seashells of western North America: marine bivalve mollusks from Arctic Alaska to Baja California: Santa Barbara: Santa Barbara Museum of Natural History Monographs, n. 2. 764 pp.

Cockerell, T.D.A. 1901. The San Clemente Island goat. Nature 65:31.

Cockerell, T.D.A. 1921a. Helix pisana in Porto Santo. Proceedings of the Malacological Society of London 14:196-197.

CockereLL, T.D.A. 1921b. Note on Craspedopoma lucidum and other Madeira shells. The Nautilus 34:113-114.

Cockerell, T.D.A. 1921c. Miscellaneous notes on land Mollusca of the Madeira Islands. The Nautilus 35: 39-40.

Cockerell, T.D.A. 1929. A new snail from Catalina Island, California. The Nautilus 42:99-100.

Cockerell, T.D.A. 1937a. Bees from San Miguel Island. Pan Pacific Entomologist 13:148-157.

Cockerell, T.D.A. 1937b. Helminthoglypta ayresiana on San Miguel Island, California. The Nautilus 51:71-72.

Cockerell, T.D.A. 1937c. The botany of the California Islands. Torreya 37:117-123.

Cockerell, T.D.A. 1937d. Letter of 28 October 1937 from Professor T.D.A. Cockerell, University of Colorado, to H.C. Bryant, Assistant Director, National Park Service, Washington, D.C. RG 79, Records of the National Park Service Western Region, Regional Director, San Francisco, CA; National Archives, San Bruno, California, Central Decimal Site Files, 1932-53, 9NS-S accession number 079-89-001, Boxes 14 and 15.

Cockerell, T.D.A. 1938a. Descriptions and records of bees. Annals and Magazine of Natural History Series II 2:146-154.

Cockerell, T.D.A. 1938b. Bees collected on the California islands in the spring of 1938. Transactions of the San Diego Society of Natural History 9:37-38.

Cockerell, T.D.A. 1938c. Studies of island life. University of Colorado Studies 26:3-20.

CockerelL, T.D.A. 1938d. San Miguel Island, California. The Scientific Monthly 46:180-187.

Cockerell, T.D.A. 1938e. A Pleistocene snail from San Miguel Island, California. The Nautilus 52:24-25.

Cockerell, T.D.A. 1939a. Bemiocid wasps from the Californian Islands. Southern California Academy of Sciences Bulletin 38:135-136.

Cockerell, T.D.A. 1939b. A new parasitic bee from Santa Catalina Island. Southern California Academy of Sciences Bulletin 38:136.

Cockerell, T.D.A. 1939c. Bees obtained by the Los Angeles Museum-Channel Islands biological survey. Southern California Academy of Sciences Bulletin 38:137-141.
Cockerell, T.D.A. 1939d. Recollections of a naturalist, XII. The California Islands. Bios 10:99-106.

Cockerell, T.D.A. 1939e. Pleistocene shells from San Clemente Island, California. Nautilus 53:22-23.

Cockerell, T.D.A. 1939f. Natural history of Santa Catalina Island. Scientific Monthly VLXIII:308-318.

Cockerell, T.D.A. 1940a. The insects of the Californian Islands. Proceedings of the Sixth Pacific Science Congress of the Pacific Science Association 4: 283-295.

CockereLL, T.D.A. 1940b. The marine invertebrate fauna of the California islands. Proceedings of the Sixth Pacific Science Congress of the Pacific Science Association 3:501-504.

Cook, L.F. 1937. Letter of 20 October 1937 from L.F. Cook, Deputy Chief Forester, National Park Service, San Francisco, California to Director, National Park Service, Washington, D.C. [with "Attention Dr. H.C. Bryant"]. RG 79, Records of the National Park Service Western Region, Regional Director, San Francisco, CA; National Archives, San Bruno, California, Central Decimal Site Files, 1932-53, 9NS-S accession number 079-89-001, Boxes 14 and 15.

Danz, H. 2000. Dr. Harold Bryant 1886-1968. Biographical Vignettes, National Park Service: The First 75 Years. https://www.nps.gov/parkhistory/online_books/ sontag/bryant.htm

Demaray, A.E. 1937. Letter of 29 October 1937 from A.E. Demaray, Acting Director, National Park Service to The Commissioner, Bureau of Lighthouses, Washington, D.C. [with cc: Region IV, Dr. Bryant, Mr. Little]. RG 79, Records of the National Park Service Western Region, Regional Director, San Francisco, CA; National Archives, San Bruno, California, Central Decimal Site Files, 1932-53, 9NS-S accession number 079-89-001, Boxes 14 and 15.

Demaray, A.E. 1938. Letter of 24 January 1938 from A.E. Demaray, Acting Director, National Park Service, to Mr. C.S. Race, Los Angeles, California. RG 79, Records of the National Park Service Western Region, Regional Director, San Francisco, CA; National Archives, San Bruno, California, Central Decimal Site Files, 1932-53, 9NS-S accession number 079-89-001, Boxes 14 and 15.

Erlandson, J.M., T.C. Rick, T.J. Braje, M. Casperson, B. Culleton, B. Fulfrost, T. Garcia, D.A. Guthrie, N. Jew, D.J. Kennett, ET AL. 2011. Paleoindian seafaring, maritime technologies, and coastal foraging on California's Channel Islands. Science 331: 1181-1185.

GrinnelL, J. 1933. Letter of 10 February 1933 from J. Grinnell, Museum of Vertebrate Zoology, University of California, Berkeley, to Thomas C. Vint, Chief Landscape Architect, National Park Service, San Francisco, CA. RG 79, Records of the National Park Service Western Region, Regional Director, San Francisco, CA; National Archives, San Bruno, California, Central Decimal Site Files, 1932-53, 9NS-S accession number 079-89-001, Boxes 14 and 15.

Hendy, I.L. 2010. The paleoclimatic response of the southern Californian margin to the rapid climate change of the last $60 \mathrm{ka}$ : a regional overview. Quaternary International 215:62-73.

HewatT, W.G. 1946. Ecological studies on Santa Cruz Island, California. Ecological Monographs 16: $185-210$. 
Howell, A.B. 1917. Birds of the islands off the coast of southern California. Cooper Ornithological Club of California. Pacific Coast Avifauna No. 12. 127 pp.

ICKES, H.L. 1938. Letter of 17 March 1938 from Harold L. Ickes, Secretary of the Interior, to Secretary of Commerce. RG 79, Records of the National Park Service Western Region, Regional Director, San Francisco, CA; National Archives, San Bruno, California, Central Decimal Site Files, 1932-53, 9NS-S accession number 079-89-001, Boxes 14 and 15.

Johnson, D.L. 1978. The origin of island mammoths and the Quaternary land bridge history of the northern Channel Islands, California. Quaternary Research 10:204-225.

Junger, A., AND D.L. Johnson. 1980. Was there a Quaternary land bridge to the northern Channel Islands? Pages 33-39 in D.M. Power, editor, The California Islands: Proceedings of Multidisciplinary Symposium: Santa Barbara Museum of Natural History, Santa Barbara, California.

KeEn, A.M. 1937. An abridged check list and bibliography of west North American marine Mollusca. Stanford University Press, Stanford, CA. 84 pp.

Kittredge, F.A. 1937. Letter of 19 October 1937 from F.A. Kittredge, Regional Director, National Park Service, to The Director, National Park Service. RG 79, Records of the National Park Service Western Region, Regional Director, San Francisco, CA; National Archives, San Bruno, California, Central Decimal Site Files, 1932-53, 9NS-S accession number 079-89-001, Boxes 14 and 15 .

Lester Roberti, B. 2008. San Miguel Island: my childhood memoir 1930-1942. Santa Cruz Island Foundation Occasional Paper 10. 130 pp.

LeVeque, N. 2000. Foreword. Pages ix-xiv in W.A. Weber, editor, The American Cockerell: a naturalist's life, 1866-1948. University Press of Colorado, Boulder, CO.

MCLEAN, J.H. 1978. Marine shells of southern California: Natural History Museum of Los Angeles County Science Series, 24 [revised]. $104 \mathrm{pp}$.

Michener, C.D. 2007. The bees of the world. 2nd edition. Johns Hopkins University Press, Baltimore, MD. 992 pp.

Miller, S.E. 1985. The California Channel Islands-past, present, and future: an entomological perspective. Pages 3-27 in A.S. Menke and D.R. Miller, editors, Entomology of the California Channel Islands, Proceedings of the First Symposium. Santa Barbara Museum of Natural History, Santa Barbara, CA.

Muhs, D.R., J. Budahn, D.L. Johnson, M. Reheis, J. Beann, G. Skipp, AND E. Fisher. 2008. Geochemical evidence for airborne dust additions to soils in Channel Islands National Park, California. Geological Society of America Bulletin 120:106-126.

Muhs, D.R., J. Budahn, M. Reheis, J. Beann, G. Skipp, AND E. Fisher. 2007. Airborne dust transport to the eastern Pacific Ocean off southern California: evidence from San Clemente Island. Journal of Geophysical Research 112:D13203. http://doi.org/10 .1029/2006JD007577

Muhs, D.R., K.R. Simmons, L.T. Groves, J.P. McGeehin, R.R. Schumann, and L.D. Agenbroad. 2015. Late Quaternary sea-level history and the antiquity of mammoths (Mammuthus exilis and Mammuthus columbi), Channel Islands National Park, California, USA. Quaternary Research 83:502-521.
Muhs, D.R., K.R. Simmons, R.R. Schumann, L.T. Groves, S.B. Devogel, S.A. Minor, and D. Laurel. 2014. Coastal tectonics on the eastern margin of the Pacific Rim: Late Quaternary sea-level history and uplift rates, Channel Islands National Park, California, USA. Quaternary Science Reviews 105:209-238.

Muns, D.R., K.R. Simmons, R.R. Schumann, L.T. Groves, J.X. Mitrovica, and D. Laurel. 2012. Sealevel history during the last interglacial complex on San Nicolas Island, California: implications for glacial isostatic adjustment processes, paleozoogeography and tectonics. Quaternary Science Reviews 37:1-25.

Pigati, J.S., J.P. McGeehin, D.R. Muhs, and E.A. Bettis III. 2013. Radiocarbon dating late Quaternary loess deposits using small terrestrial gastropod shells. Quaternary Science Reviews 76:114-128.

Pigati, J.S., D.R. Muhs, and J.P. McGeehin. 2017. On the importance of stratigraphic control for vertebrate fossil sites in Channel Islands National Park, California, USA: examples from new Mammuthus finds on San Miguel Island. Quaternary International 443: 129-139.

Pigati, J.S., J.A. Rech, and J.C. Nekola. 2010. Radiocarbon dating of small terrestrial gastropod shells in North America. Quaternary Geochronology 5: 519-532.

ReED, R.D. 1933. Geology of California. American Association of Petroleum Geologists Special Publication 2. $355 \mathrm{pp}$.

Rhodes, H.W. 1932. Letter dated 15 July 1932 from H.W. Rhodes, Superintendent of Lighthouses to Chief Landscape Architect, National Park Service, San Francisco, California. RG 79, Records of the National Park Service Western Region, Regional Director, San Francisco, CA; National Archives, San Bruno, California, Central Decimal Site Files, 193253, 9NS-S accession number 079-89-001, Boxes 14 and 15 .

Roberts, L.J. 1991. San Miguel Island: Santa Barbara’s Fourth Island West. Carmel, California, Cal Rim Books. 214 pp.

Russell, M.P. 1991. Modern death assemblages and Pleistocene fossil assemblages in open coast high energy environments, San Nicolas Island, California. Palaios 6:179-191.

Rust, R., A. Menke, and D. Miller. 1985. A biogeographic comparison of the bees, sphecid wasps, and mealybugs of the California Channel Islands (Hymenoptera, Homoptera). Pages 29-59 in A.S. Menke and D.R. Miller, editors, Entomology of the California Channel Islands, Proceedings of the First Symposium. Santa Barbara Museum of Natural History, Santa Barbara, CA.

SEAPY, R.R., AND M.M. LitTler. 1993. Rocky intertidal macroinvertebrates of the Southern California Bight: an overview and checklist. Pages 293-322 in F.G. Hochberg, editor, Third California Islands Symposium: recent advances in research on the California Islands. Santa Barbara Museum of Natural History, Santa Barbara, CA.

SetcheLl, W.A. 1933. Letter of 9 February 1933, interpreted to be from W.A. Setchell, Department of Botany, University of California, Berkeley [last page is missing] to Thomas C. Vint, Chief Landscape Architect, National Park Service, San Francisco, CA. RG 79, Records of the National Park Service 
Western Region, Regional Director, San Francisco, CA; National Archives, San Bruno, California, Central Decimal Site Files, 1932-53, 9NS-S accession number 079-89-001, Boxes 14 and 15.

Shettle, M.L., Jr. 1997. United States Naval air stations of World War II, Volume 2. Schaertel Publishing, Inc., 285 pp.

Simpson, G.G. 1940. Mammals and land bridges. Journal of the Washington Academy of Sciences 30:137-163.

Spalding, M.D., H.E. Fox, G.R. Allen, N. Davidson, Z.A. Ferdaña, M. Finlayson, B.S. Halpern, M.A. Jorge, A. Lombana, S.A. Lourie, Et AL. 2007. Marine ecoregions of the world: a bioregionalization of coastal and shelf areas. BioScience 57:573-583.

TAYLOR, R.E. 1992. Radiocarbon dating of bone: to collagen and beyond. Pages 375-402 in R.E. Taylor, A. Long, and R.S. Kra, editors, Radiocarbon after four decades: an interdisciplinary perspective. SpringerVerlag, New York, NY.

Valentine, J.W. 1966. Numerical analysis of marine molluscan ranges on the extra-tropical northeastern Pacific shelf. Limnology and Oceanography 11: $198-211$.

VALEnTine, J.W. 1973. Evolutionary paleoecology of the marine biosphere. Prentice-Hall, Inc., Englewood Cliffs, NJ. 511 pp.

Vedder, J.G., AND D.R. Howell. 1980. Topographic evolution of the Southern California Borderland during late Cenozoic time. Pages 7-31 in D.M. Power, editor, The California Islands: Proceedings of Multidisciplinary Symposium: Santa Barbara Museum of Natural History, Santa Barbara, CA.

Vedder, J.G., And R.M. NorRis. 1963. Geology of San Nicolas Island California. U.S. Geological Survey Professional Paper 369. 65 pp.

Wallace, A.R. 1895. Island life: or, the phenomena and causes of insular faunas and floras, including a revision and attempted solution of the problem of geological climates. 2nd edition. MacMillan and Co., London.

Weaver, D.W., AND D.P. DoERner. 1967. Western Anacapia-a summary of the Cenozoic history of the northern Channel Islands. Pages 13-20 in R.N. Philbrick, editor, Proceedings of the Symposium on the Biology of the California Islands, Santa Barbara Botanic Garden, Santa Barbara, CA.

Weber, W.A. 1965. Theodore Dru Alison Cockerell, 1866-1948. University of Colorado Studies, Series in Bibliography No. 1. University of Colorado Press, Boulder, CO. 124 pp.

Weber, W.A. 2000. The American Cockerell: a naturalist's life, 1866-1948. Boulder, University Press of Colorado, CO. 352 pp.

Weber, W.A. 2004. The Valley of the Second Sons: Letters of Theodore Dru Alison Cockerell, a young English naturalist, writing to his sweetheart and her brother about his life in West Cliff, Wet Mountain Valley, Colorado, 1887-1890. Pilgrims Process, Inc., Longmont, CO. 567 pp.

Wenner, A.M., AND D.L. Johnson. 1980. Land vertebrates on the California Channel Islands: sweepstakes or bridges? Pages 497-530 in D.M. Power, editor, The California Islands: Proceedings of Multidisciplinary Symposium. Santa Barbara Museum of Natural History, Santa Barbara, CA.

Wilson, J.S., and O.J. Messinger Carril. 2015. The bees in your backyard: a guide to North America's bees. Princeton University Press, Princeton, NJ. 288 pp.

Received 1 March 2017

Revised 15 November 2017

Accepted 28 November 2017

Published online 6 April 2018 